\title{
Ultrasensitive Aptasensors for the Detection of Viruses Based on Opto-Electrochemical Readout Systems
}

\author{
Divya (D), Daphika S Dkhar D, Rohini Kumari, Supratim Mahapatra (D), Rahul Kumar and Pranjal Chandra *(D)
}

\author{
Laboratory of Bio-Physio Sensors and Nanobioengineering, School of Biochemical Engineering, Indian Institute of \\ Technology (BHU) Varanasi, Varanasi 221005, Uttar Pradesh, India; divya.rs.bce20@itbhu.ac.in (D.); \\ daphikasdkhar.rs.bce21@itbhu.ac.in (D.S.D.); rohinikumari.rs.bce21@itbhu.ac.in (R.K.); \\ supratimmahapatra.rs.bce20@itbhu.ac.in (S.M.); rahulk.rs.bce16@itbhu.ac.in (R.K.) \\ * Correspondence: pranjal.bce@iitbhu.ac.in
}

check for updates

Citation: Divya; Dkhar, D.S.; Kumari, R.; Mahapatra, S.; Kumar, R.; Chandra, P. Ultrasensitive Aptasensors for the Detection of Viruses Based on OptoElectrochemical Readout Systems. Biosensors 2022, 12, 81. https:// doi.org/10.3390/bios12020081

Received: 31 December 2021 Accepted: 27 January 2022

Published: 29 January 2022

Publisher's Note: MDPI stays neutral with regard to jurisdictional claims in published maps and institutional affiliations.

Copyright: (C) 2022 by the authors. Licensee MDPI, Basel, Switzerland. This article is an open access article distributed under the terms and conditions of the Creative Commons Attribution (CC BY) license (https:// creativecommons.org/licenses/by/ $4.0 /)$.
Abstract: Viral infections are becoming the foremost driver of morbidity, mortality and economic loss all around the world. Treatment for diseases associated to some deadly viruses are challenging tasks, due to lack of infrastructure, finance and availability of rapid, accurate and easy-to-use detection methods or devices. The emergence of biosensors has proven to be a success in the field of diagnosis to overcome the challenges associated with traditional methods. Furthermore, the incorporation of aptamers as bio-recognition elements in the design of biosensors has paved a way towards rapid, cost-effective, and specific detection devices which are insensitive to changes in the environment. In the last decade, aptamers have emerged to be suitable and efficient biorecognition elements for the detection of different kinds of analytes, such as metal ions, small and macro molecules, and even cells. The signal generation in the detection process depends on different parameters; one such parameter is whether the labelled molecule is incorporated or not for monitoring the sensing process. Based on the labelling, biosensors are classified as label or label-free; both have their significant advantages and disadvantages. Here, we have primarily reviewed the advantages for using aptamers in the transduction system of sensing devices. Furthermore, the labelled and label-free opto-electrochemical aptasensors for the detection of various kinds of viruses have been discussed. Moreover, numerous globally developed aptasensors for the sensing of different types of viruses have been illustrated and explained in tabulated form.

Keywords: aptamers; viral infection; COVID-19; human health; digital health; biosensor

\section{Introduction}

According to the World Health Organization, hundreds of millions of people have viral infections every year, with millions of death worldwide [1]. Figure 1A illustrates the the outbreak of few major viral infections that have created havoc in the human population over the past few centuries. The current situation of the COVID-19 pandemic has brought scientist's focus towards infectious diseases caused by viruses. The ongoing pandemic by novel SARS-CoV-2 has reported more than 284 million infections and claimed around 5.4 million deaths [2]. In addition to this, various other viruses, such as HIV, Dengue, Zika, Ebola, West Nile, etc., lead to a large number of human infections and deaths. Therefore, simple, fast, accurate, and specific diagnostic techniques are in great demand for the early diagnosis, prognosis and surveillance of diseases, by targeting particular biomarkers/target sites. There are some reliable techniques which exist for virus detection such as cell culture, hemagglutination inhibition test, immuno-complexation, etc [3,4]. Furthermore, with advancement in technology, a few other techniques, for instance, ELISA, RIA, serological and PCR methods, have also been employed for virus detection [5,6]. However, these methods are costly, time consuming, and require laboratory infrastructure and skilled personnel. In contrast to these methods, point-of-care (POC) diagnostic tools have attracted 
more attention for their rapid, easy, and inexpensive detection methods, especially in the developing nations, which lacks proper infrastructure and trained individuals [7-9]. Additionally, owing to their excellent properties, POC devices have become very significant in the prevention and control of various viral infections [10-13]. Aptasensors are one of the most advanced diagnostic techniques, exhibiting excellent properties and great potential for the detection of viruses, especially in resource-constrained areas [14]. Aptamers were discovered in 1990, and since then they have been extensively used as molecular recognition elements in a large number of applications [15-17]. This is because they can probe for different targets, for example metal ions, small and macro molecules, and even cells with high selectivity and sensitivity. Biosensors are the analytical devices which modulates the signal obtained from the interaction between the biorecognition element (BRE) and the target molecule $[18,19]$. When aptamers are used as a BRE in biosensors to track a specific target or biomarker, an aptasensor is formed. The basic principle of designing and functioning of aptasensor, starting from the specific aptamer selection to signal generation, is represented in Figure 2. The signal obtained in the sensor can be in the form of a colour change, fluorescence, electrochemical parameters, mechanical parameters, etc [20-24].

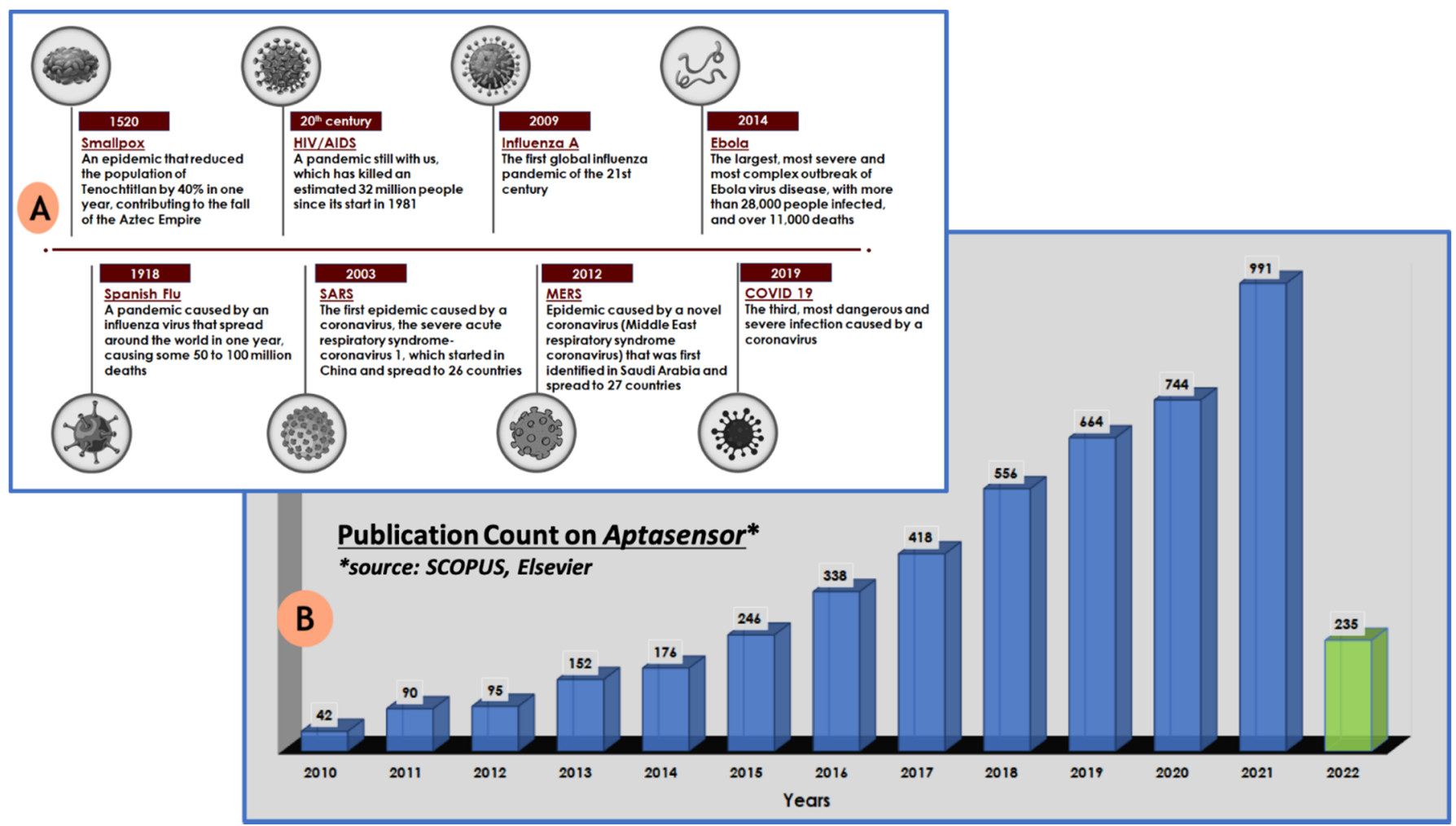

Figure 1. (A) Timeline of the major virus outbreaks that have occurred in past centuries that have created havoc to mankind; (B) graphical representation of the Scopus, Elsevier survey representing the growing interest towards aptasensors in the last decade. 


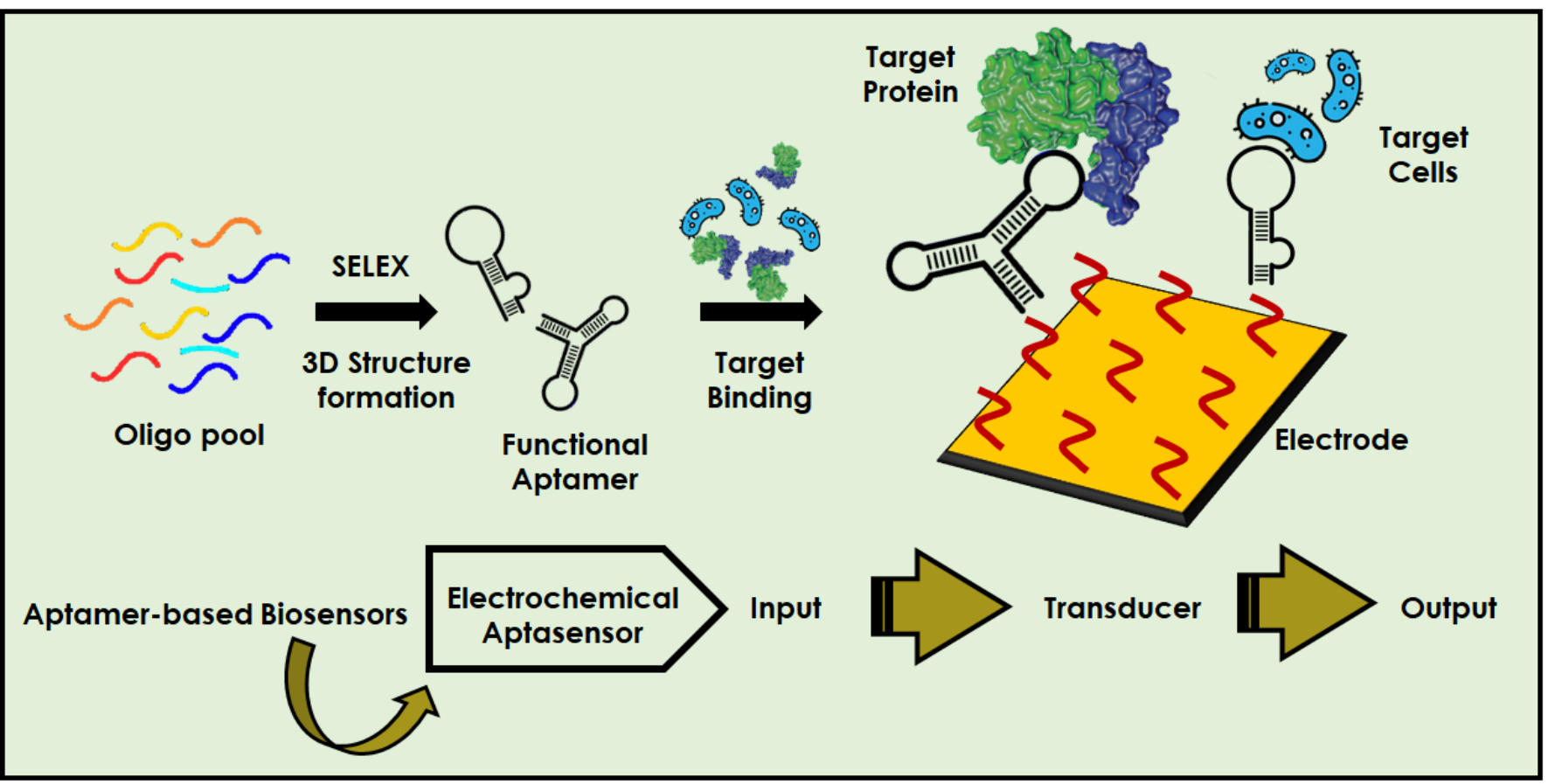

Figure 2. Pictorial representation of step-by-step fabrication procedure of aptasensors for the detection of various target molecules.

This review mainly focuses on determining the change in optical and electrochemical parameters i.e., current, potential, voltage, colour, phase change, etc., which comes under the class of opto-electrochemical biosensors. Furthermore, we have explored the labelled and label-free aptasensors for the detection of viral infections. The labelled and label-free aptasensors are classified according to the different signal readout system, for instance electrochemical and optical signals. Moreover, the globally developed aptasensors for the virus monitoring have been comprehensively discussed and represented in various figures. Significant attention is given to the fabrication process and how the aptamers are incorporated in the design of aptasensors for various targets. Various fabricated aptasensors, especially in the last 3 years, have been explained in tabulated form, describing their readout system and analytical details, such as dynamic range, limit of detection (LOD), aptamer sequence, labelling molecule, etc. Finally, we summarise and present an insight towards the future of aptasensors, speculating on how they will become more convenient, cost-effective, rapid test devices.

\section{Label and Label-Free Aptasensors}

\subsection{Aptamers and Biosensors}

Aptamers are single-stranded oligonucleotide sequences (DNA or RNA) that may fold into a stable three-dimensional (3D) structure and interact with a target molecule, both sterically, and through electrostatic interactions. The electrostatic complementarity occurs because of an interaction between the positive and negative charges present on the surfaces of the aptamer and the target. Apart from the electrostatic interaction, other intermolecular interactions such as van der Waals forces, hydrogen bonds and $\pi$ - $\pi$ stacking make the aptamer-target complex stable [25]. They feature distinct characteristics such as compact size, low cost, high specificity, facile chemical modification, and most importantly extraordinary flexibility. These are capable of binding specific targets with high affinity, specificity, and sensitivity [26,27]. The target molecule can be as simple as a metal ion, and can be as complex as large protein molecules such as cardiac troponin, or even cells [28-32]. Aptamers are designed by an easier, cheaper in vitro method called SELEX (systematic evolution of ligands by exponential enrichment) $[33,34]$. This simple but elegant technique 
was discovered by a group of scientists—Larry Gold and Jack Szostak—and published for the first time in 1990 [35,36]. Because of the in vitro selection method of aptamers, this allows us to engineer the affinity molecules which are non-immunogenic or toxic to the cells. The chemical synthesis method of aptamers is easy and cost-effective, and warranties a high-level consistency from batch-to-batch [37]. Aptamers show numerous advantages over antibodies, including a low cost of development, high stability, sensitivity, and an easier modification process. In addition, they are not immunogenic [38-41]. Moreover, their insensitivity towards any change in $\mathrm{pH}$, temperature, and ionic strength make them a preferred choice over antibodies. In the year 1996, fluorescently labelled aptamer was first reported to be utilized as a bio-detection agent in biosensors [42-45]. In the last decade, the implementation of aptamers has increased exponentially in the design of biosensors. This exponential increase is concluded from a scientific survey performed on SCOPUS for the number of research articles published with the keyword "aptasensor", especially in last decade (Figure 1B).

Biosensors are analytical devices that provide detection of target analytes, both qualitatively and quantitatively [38-40]. Biosensors show excellent potential to fulfil the ASSURED criteria (i.e., affordable, sensitive, specific, user-friendly, rapid and robust, equipment-free and deliverable to users) for developing point-of-care devices [46]. There are three essential components of any type of biosensor, i.e., BRE, transducer, and an amplifier and processor. The selection of ideal substrate is also one of the important and challenging tasks the in fabrication of biosensors [22]. On the basis that transduction system biosensors can be categorized in different classes such as electrochemical, optical, mechanical, etc. [47-50], in this study, a detailed focus is given on the optical and electrochemical aspect of the transduction system. Electrochemical biosensors measure the signal based on any minute difference in potential, conductance, current, or field effect that occurs because of the binding between the BRE and the analyte [51,52]. These systems are preferred over others because of their selectivity, sensitivity, and operational details [53-56]. The three electrodes typically used in an electrochemical system include; the working electrode (e.g., glassy carbon electrode functions as the transducing element); the auxiliary/counter electrode (e.g., Pt electrode, acts to complete the circuit); and the reference electrode (e.g., $\mathrm{Ag} / \mathrm{AgCl}$ electrode, important for creating a steady potential) [24,57-59]. The important task in this system is selecting the suitable working electrode according to the need for modification and surface nano-engineering to target a specific analyte. The basic principle behind the working of such biosensors is the electron or ion transfer kinetics from the reaction point to the surface of electrode [60-62]. In both labelled and label-free electrochemical biosensors, any change (positive or negative) in electron transport is monitored. Numerous techniques have been developed to study the change in various parameters (potential, current, charge, time, conductivity, impedance), for instance, Cyclic Voltammetry (CV), chronoamperometry, differential pulse voltammetry, square wave voltammetry, etc. Another electrochemical technique, i.e., electrochemical impedance spectroscopy (EIS), is used to study the electrochemical kinetics of sensing surfaces through inducing the electrochemical kinetics on working electrodes [63-66]. All these techniques aid in detecting any changes occurring on the surface of electrodes, such as whether the BRE (such as the aptamer) has bound or not. For instance, an electrochemical aptasensor for the detection of SARS-CoV-2 has recently been designed by Abrego-Martinez et al., in 2021. In this sensor, screen-printed carbon electrode (SPCE) was used and modified with AuNPs, after which an aptamer was immobilised on the electrode surface illustrated in Figure 3A. The change in electrochemical parameters with every step of modification on SPCE and the fabrication of the aptasensor was monitored by CV and EIS, as shown in Figure 3B,C, respectively. All these recordings were performed in phosphate buffer saline solution containing $5 \mathrm{mM}\left[\mathrm{Fe}(\mathrm{CN})_{6}\right]^{3-/ 4-}$ [67]. 


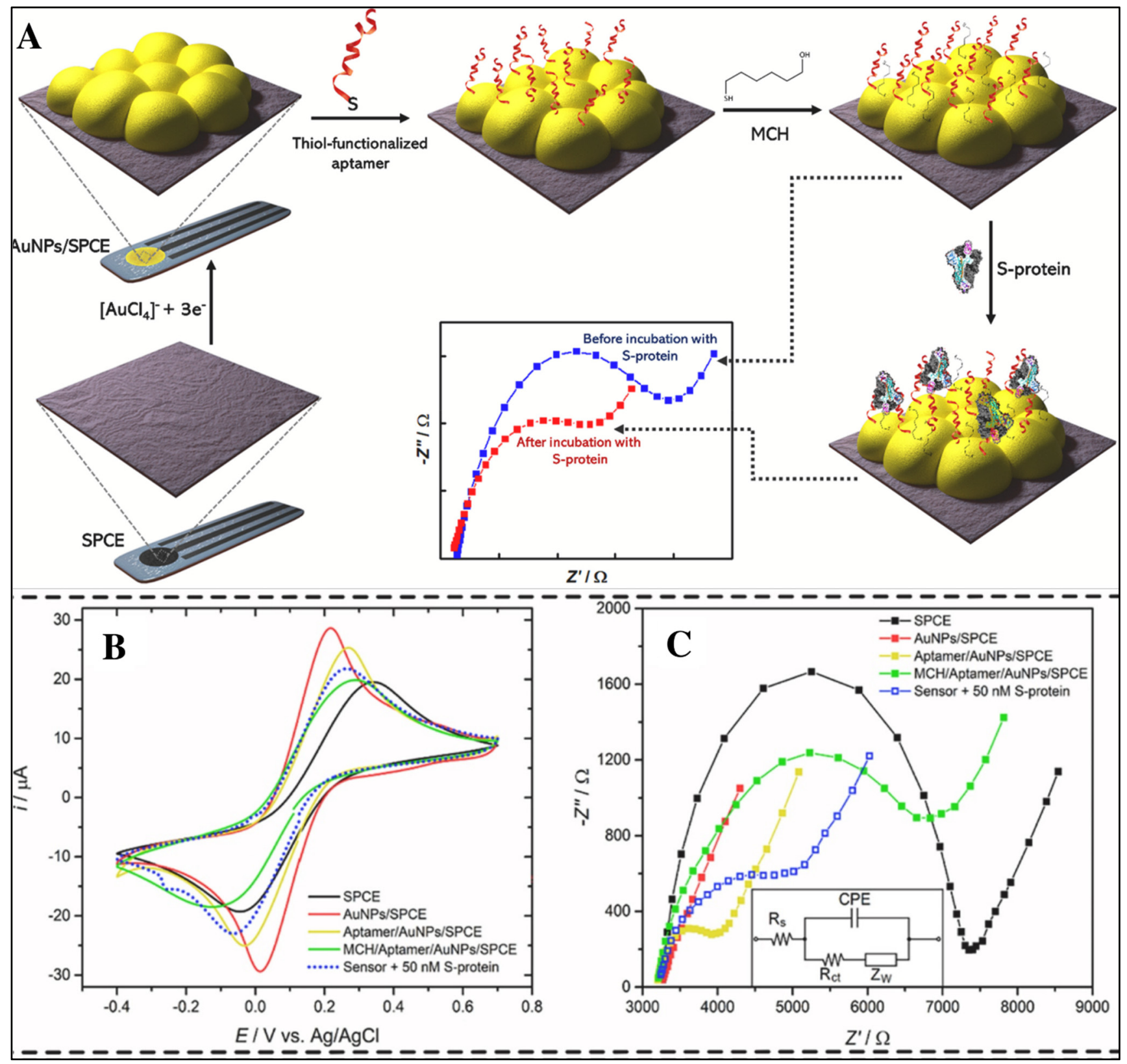

Figure 3. (A) Step-by-step fabrication of aptasensor for the detection of SARS-CoV-2 by targeting the receptor-binding domain. (B) Representation of CV. (C) EIS results for every step of the aptasensor fabrication and detection of SARS-CoV-2 (reprinted with permission from [67]. Copyright 2021 Elsevier).

Optical biosensors allow us to analyse the polarity, phase or frequency change in the optical field of a BRE, due to interaction with the target. Optical biosensors can further be categorized into luminescence, absorption, or fluorescence-based, on the basis of the transduction mechanism [68]. Optical biosensors based on change in refractive indexes are one of the most preferred, because of their great performance, low cost, and user-friendly nature. This type of sensors helps in the miniaturization of devices due to the absence of complex reactions, and in developing multiplexing devices $[69,70]$. In this class, the direct detection or naked-eye-based optical system (labelled and label-free) are common, due to their simple and fast detection procedure. For instance, Chen et al., 2021, have developed an aptasensor based on surface-enhanced Raman scattering (SERS) for the detection of influenza virus A (H1N1) virus by immobilizing a labelling probe, i.e., Cy3 with an aptamer on the nanostructure surface. A strong Raman signal was generated 
when the Cy3 label attached to the aptamer and a further interaction of the label with the target (Hemagglutinin) shows the reduction in Raman signal, as illustrated in Figure 4A,B, respectively [71].
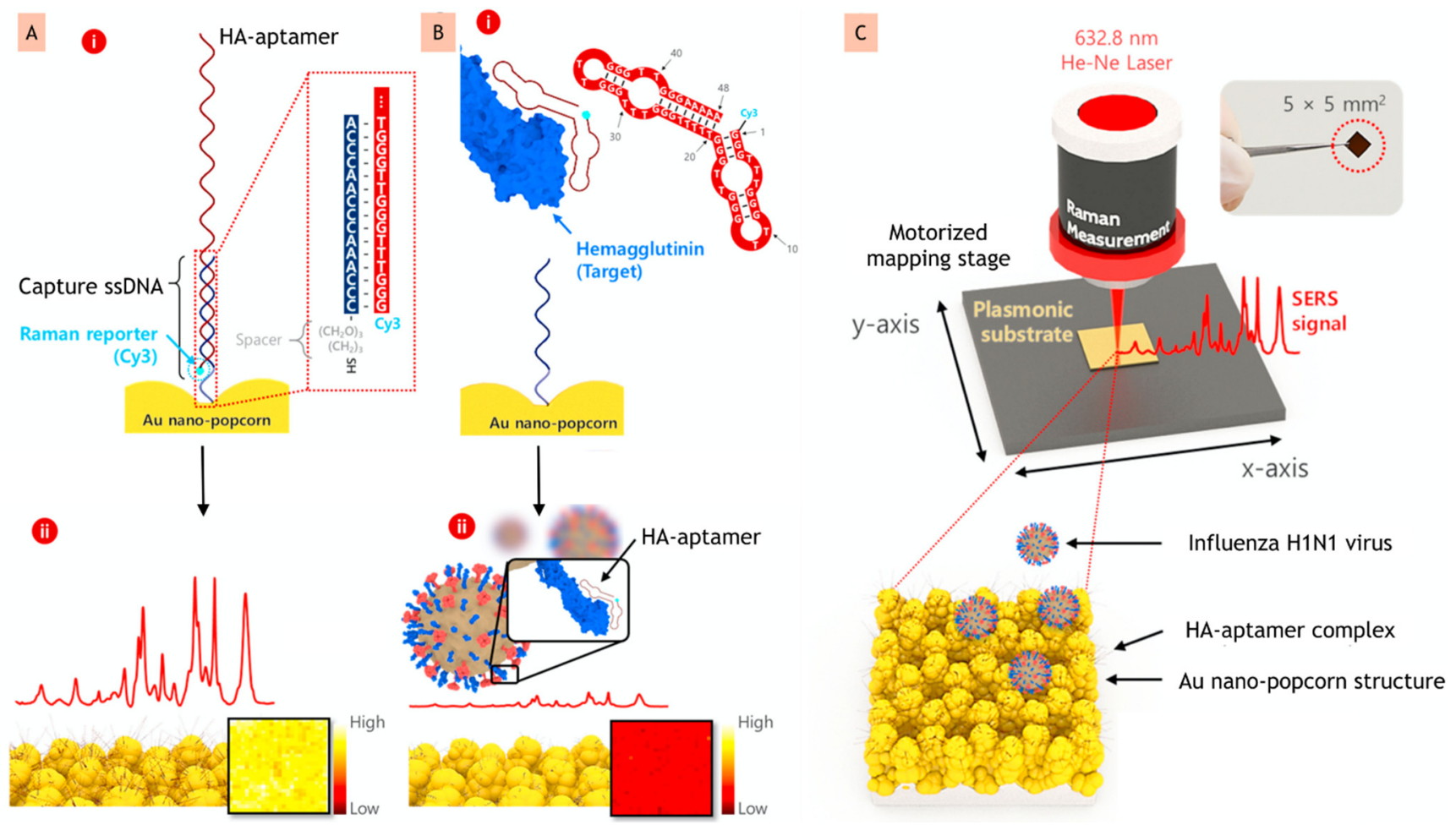

Figure 4. (A) (i) Aptamer probe labelled with Cy-3 on the surface of nano-popcorn; (ii) strong Raman signal created by labelled structure. (B) (i) Representation of conformational change that occurred due to recognition of $\mathrm{A} / \mathrm{H} 1 \mathrm{~N} 1$ virus; (ii) effect of recognition on Raman signal. (C) Schematic representation of the SERS-based aptasensor by utilizing a 3D nano-popcorn for the detection of A/H1N1 virus quantitatively (reprinted with permission from [71]. Copyright 2020 Elsevier).

\subsection{Labelled Opto-Electrochemical Aptasensors for Virus Detection}

Aptasensors are classified into two types, namely, labelled and label-free, depending upon whether the labelling molecule is used for signal enhancement/generation or not. A label is a foreign molecule which is bonded through chemical or physical means to monitor the target analyte. Numerous kinds of molecules are used as labels, for example, fluorophores, enzymes, dyes, etc. In the earlier days of biosensors development, various kinds of optical or radioactive molecules were used as labels inspired from conventional electrophoresis ELISA techniques [72-74]. Label-based sensing systems utilize various types of transducing systems for signal detection, such as colorimetric, electrochemical, electro-chemiluminescence, SERS, etc. Labels are employed in electrochemical biosensors to boost the signal produced per occurrence. Electrochemical labelling often involves chemical methods that covalently bind labels, but some probe labelling merely requires momentary (physical-binding) attachments [75-77]. In one of the fascinating studies, Karash et al. designed an impedance-based aptasensor utilizing a specific avian influenza virus (AIV) H5N1 aptamer and a gold interdigitated microelectrode. In this, the biotin-tagged H5N1 aptamer was coupled to incorporate streptavidin on the microelectrode surface. The virus was captured by the attached aptamer after polyethylene glycol was used as a blocking agent on the microelectrode surface. Furthermore, an amplifier was prepared based on nanoparticles and applied to improve the impedance signal by establishing a pattern-like AuNP/H5N1-aptamer/thiocyanuric acid system. The impedance aptasensor showed a detection limit of $0.25 \mathrm{HAU}$ (hemagglutinations unit) for pure virus, and for H5N1 virus-spiked tracheal chicken swab samples the limit was 1 HAU. The system was able to 
explicitly detect the subtype H5N1 using specialized aptamers that bound to the virus, but not the nonspecific virus. This aptasensor was proven to boost impedance signal change by at least 48 times, laying the groundwork for the creation of a portable and cost-effective technique [78]. Similarly, in another work, Xu et al. developed a fluorescent-based hydrogel aptasensor for the fast sensing of H5N1. An aptamer was selected specifically for H5N1, and two partially complementary single-stranded DNAs (ssDNA1 and ssDNA2) were created for the attachment to aptamer's two ends. Furthermore, for hydrogel production via polymerization, both aptamer and ssDNA1 were functionalized with acrydite at the $5^{\prime}$-terminus. Quantum dots (QDs) were tagged at the $5^{\prime}$-terminal of ssDNA2 as fluorescence reporters, and at the $3^{\prime}$-terminal of the aptamer, quenchers for QDs were coupled. The crosslinker for the QD-aptamer hydrogel was generated by hybridization between the aptamer and ssDNAs. When the target binds, the crosslinking between the aptamer and target get segregated, because of the binding reaction between them, causing the hydrogel to suddenly inflate and the liberation of the aptamer-quencher and ssDNA2-QDs. The quartz crystal microbalance method was used as a readout system to reveal the aptamer's responsiveness to target binding. From sampling to results, it took $30 \mathrm{~min}$ to complete the detection process. The detection range was found to be $2^{-1.2}-26 \mathrm{HAU} 20 \mu \mathrm{L}^{-1}$, with an LOD of $0.4 \mathrm{HAU}$. The suggested method is a quick, simple, specific and label-free assay, that can be expanded further as a generic and practical detection platform, with benefits such as: (1) when specific aptamers are available, QDs with distinct emission wavelengths can be used to detect several targets at the same time; (2) the idea of developing a portable apparatus could be realized through the dropping of hydrogel in a solid substrate for detection; (3) the properties which are affected by the size of the hydrogel-based aptasensor provide a viable technique to develop a recognition pattern of aptamer-hydrogel with an optimal pore size and crosslinking density for certain analytes [79].

Apart from the implication of labelled aptasensors in H5N1 detection, they are also exploited for the detection of other viruses. For instance, in a recent study, Chen et al. developed a SERS imaging-based aptasensor for the sensitive and repeatable spotting of H1N1 by targeting the Hemagglutinin protein [71]. They used the difference in surface energy between a spacer (made of perfluoro decanethiol) and a Au layer to fabricate a plasmonic substrate of 3D nano-popcorn (Figure 4C). This differential energy caused Au nanoparticles to self-assemble, resulting in numerous hotspots on the substrate. To obtain a robust Raman signal, the aptamer probe was labelled with Cy3 and hybridized with thiolated capture DNAs anchored on the 3D nano-popcorn surface. The incident field was greatly amplified by localized surface plasmon effects in the hotspot areas. The LOD and assay duration of the developed A/H1N1 virus aptasensor were estimated to be 97 PFU (Plaque Forming Unit) $\mathrm{mL}^{-1}$ and $20 \mathrm{~min}$, respectively. PFU is mainly used in virology as a measure to describe the number of virus particles capable of forming plaques per unit volume. The suggested SERS-based image aptasensor platform solves the drawbacks of traditional techniques, i.e., time-consuming, labor-intensive RT-PCR (reverse transcriptase-polymerase chain reaction), minimal sensitivity and quantitative analytical limits of lateral flow assay kits. Mok et al., 2021, designed a one-shot labelled aptasensor for the detection of the Dengue virus non-structural protein (NS1). In this study, a G-quadruplex-forming Dengue virus-derived NS1-binding aptamer (DBA) was developed and further labelled with a fluorescent dye 6-carboxy fluorescein (FAM) at the $5^{\prime}$ end. Optical sensing is achieved by the detection of the structural destruction of DBA, which is induced by the NS1 protein. The 5'FAM-DBA quantitatively detects the fluorescence quenching brought about by Guanines upon NS1 binding. The constructed one shot, simple, rapid aptasensor achieved an LOD of $8.13 \mathrm{nM}$ and a wide dynamic range of $2.81 \mathrm{nM}$ to $360 \mathrm{nM}$ [80]. Because of the enormous impact of aptamers, different groups of researchers are working on exploring this field, and aptasensors are being developed worldwide for different targets. Therefore, apart from the above explained examples, various other developed labelled aptasensors have been mentioned in Table 1, describing the target, labelling molecule, aptamer sequence, and analytical details. 
Table 1. Labelled opto-electrochemical aptasensor for virus detection (NR—not reported).

\begin{tabular}{|c|c|c|c|c|c|c|c|c|c|}
\hline Sl.No & Target & $\begin{array}{l}\text { Target Genetic } \\
\text { Material } \\
\text { (RNA/DNA) }\end{array}$ & Labelling Molecule & Aptamer Sequence & Binding Description & Detection Range & LOD & Detection Method & References \\
\hline 1 & H1N1 & RNA & Сy3 (Cyanine dye 3) & $\begin{array}{l}\text { Probe: } 5^{\prime}-\mathrm{Cy} 3 / \text { GGGTTTGGGTTGGG } \\
\text { TTGGGTTTTTGGGTTTGGGTTGGGTT } \\
\text { GGGAAAAA-3' } \\
\text { Capture: } \text { 5'-ACCCAACCCAAACCC- }^{\prime}-\mathrm{ACC}^{\prime} \\
\left(\mathrm{CH}_{2} \mathrm{O}\right)_{3}\left(\mathrm{CH}_{2}\right)_{3}-\mathrm{SH}-3^{\prime}\end{array}$ & $\begin{array}{l}\text { Target induces aptamer } \\
\text { to form DNA duplex }\end{array}$ & $10-10,000 \mathrm{PFU} \mathrm{mL} \mathrm{m}^{-1}$ & $97 \mathrm{PFU} \mathrm{mL}^{-1}$ & SERS & {$[71]$} \\
\hline 2 & $\begin{array}{l}\text { Influenza } \\
\text { virus }\end{array}$ & RNA & Су3 & $\begin{array}{l}\text { Primary aptamer: } 5^{\prime} \text {-HS-(}\left(\mathrm{CH}_{2}\right)_{6} \text {-TTGG } \\
\text { GGTTATTTTGGGAGGGCGGGGGTT-3' } \\
\text { Secondary aptamer: 5'-Cy3-TTG } \\
\text { GGGTTATTTTGGGAGGGGGGGGTT-3' }\end{array}$ & $\begin{array}{l}\text { Aptamer binds to the } \\
\text { surface of target }\end{array}$ & $2.5 \times 10^{-4}-1.3 \mathrm{HAU} \mathrm{mL}{ }^{-1}$ & $1 \times 10^{-4} \mathrm{HAU} \mathrm{mL}^{-1}$ & SERS & [81] \\
\hline 4 & HIV & RNA & $\begin{array}{l}\text { Europium sulfide } \\
\text { nanocrystals } \\
\text { (EsNCs) }\end{array}$ & $\begin{array}{l}\text { 5'-NH } 2 \text {-GGGGGGCCAAGGCCCAGCCC } \\
\text { TCACACA-3' }\end{array}$ & $\begin{array}{l}\text { Target induces ssDNA } \\
\text { aptamer to form DNA } \\
\text { duplex }\end{array}$ & $3.0 \mathrm{fM}-0.3 \mathrm{nM}$ & $0.3 \mathrm{fM}$ & Electrochemiluminescence & [83] \\
\hline 5 & HBV & DNA & Methylene Blue & $\begin{array}{l}5^{\prime} \text {-SH-( }\left(\mathrm{CH}_{2}\right)_{6} \text {-GGGAATTCGAGCTCGG } \\
\text { TACCGGCACAAGCATATGGACTCCTCT } \\
\text { GAACCTACGATGTAGTACCTGCAGGCA } \\
\text { TGCAAGCTTGG-3 }\end{array}$ & $\begin{array}{l}\text { Target induces ssDNA } \\
\text { aptamer to form DNA } \\
\text { duplex }\end{array}$ & $0.125-2.0 \mathrm{fg} \mathrm{mL}^{-1}$ & $0.0014 \mathrm{fg} \mathrm{mL}^{-1}$ & Electrochemical & [84] \\
\hline 6 & $\mathrm{HBV}$ & DNA & $\begin{array}{l}\text { ALP-labeled } \\
\text { Streptavidin }\end{array}$ & $\begin{array}{l}\text { S1: 5'-CACAGCGAACAGCGGCGGA } \\
\text { CATAATAGTGCTTACTACGAC-3' } \\
\text { S2: 5'-CGAGCTCGAATTCCCGATC } \\
\text { TCTAG-SH-3' } \\
\text { S3: 5' } \text { 5'Biotin-TCGCAGTGT-SH-3' }^{\prime}\end{array}$ & $\begin{array}{l}\text { Aptamer binds to } \\
\text { target surface }\end{array}$ & $1-225 \mathrm{ng} \mathrm{mL}^{-1}$ & $0.05 \mathrm{ng} \mathrm{mL}^{-1}$ & Chemiluminescence & [85] \\
\hline 7 & Flavivirus & RNA & $\begin{array}{l}\text { 6-carboxyfluorescein } \\
\text { (FAM) }\end{array}$ & $\begin{array}{l}\text { 5'-FAM-AGCGGATCCGATGGGTGGGG } \\
\text { GGGTGGGTAGGATCCGCG-3' }\end{array}$ & $\begin{array}{l}\text { Target induces aptamer } \\
\text { structure } \\
\text { (G-Quadruplex) } \\
\text { destruction }\end{array}$ & $2.81 \mathrm{nM}-360 \mathrm{nM}$ & $8.13 \mathrm{nM}$ in serum. & Fluorometric & [80] \\
\hline 8 & Norovirus & RNA & 6-carboxyfluorescein & $\begin{array}{l}\text { 5'-AGTATACGTATTACCTGCAGCCCATG } \\
\text { TTTTGTAGGTGTAATAGGTCATGTTAGG } \\
\text { GTTTCTGCGATATCTCGGAGATCTTGC-3' }\end{array}$ & $\begin{array}{l}\text { Binding of aptamer to } \\
\text { the target surface }\end{array}$ & $13 \mathrm{ng} \mathrm{mL}^{-1}-13 \mu \mathrm{g} \mathrm{mL}^{-1}$ & $\begin{array}{l}4.4 \mathrm{ng} \mathrm{mL}^{-1}(\mathrm{MWCNT}) \\
3.3 \mathrm{ng} \mathrm{mL}^{-1}(\mathrm{GO})\end{array}$ & Fluorometric & [86] \\
\hline 9 & $\begin{array}{l}\text { MERS-CoV- } \\
2\end{array}$ & RNA & Methylene blue & $\begin{array}{l}\text { S-19 aptamer: } \text { 5'-TGACACCGTACCTGCT }^{\prime} \text { CTGCACTTCCTTCACCAGAAACCTGCA } \\
\text { CATCTTCGCCGCGTGAAGCACGCCAA } \\
\text { GGGACTAT-3' }{ }^{\prime}\end{array}$ & $\begin{array}{l}\text { Aptamer targets the } S \\
\text { protein }\end{array}$ & $\begin{array}{l}1 \mathrm{pg} \mathrm{mL}^{-1}-1 \mathrm{ng} \mathrm{mL}^{-1} \\
1 \mathrm{pg} \mathrm{mL}^{-1}-1 \mathrm{ng} \mathrm{mL}^{-1}\end{array}$ & $\begin{array}{l}0.525 \mathrm{pg} \mathrm{mL}^{-1} \\
0.645 \mathrm{pg} \mathrm{mL}^{-1}\end{array}$ & $\begin{array}{l}\text { Electrochemical } \\
\text { SERS }\end{array}$ & [87] \\
\hline 10 & SARS-CoV-2 & RNA & $\begin{array}{l}\text { HRP and hemin/G } \\
\text { quadruplex } \\
\text { DNAzyme }\end{array}$ & NR & $\begin{array}{l}\text { Target induces aptamer } \\
\text { to form } \\
\text { G-quadruplexes }\end{array}$ & $0.025-50 \mathrm{ng} \mathrm{mL}^{-1}$ & $8.33 \mathrm{pg} \mathrm{mL}^{-1}$ & Electrochemical & [88] \\
\hline
\end{tabular}


Table 1. Cont.

\begin{tabular}{|c|c|c|c|c|c|c|c|c|c|}
\hline Sl.No & Target & $\begin{array}{l}\text { Target Genetic } \\
\text { Material } \\
\text { (RNA/DNA) }\end{array}$ & Labelling Molecule & Aptamer Sequence & Binding Description & Detection Range & LOD & Detection Method & References \\
\hline 11 & SARS-CoV-2 & RNA & Сy3 Raman reporter & $\begin{array}{l}\text { Probe: } 5^{\prime} \text {-Cy3/TTTTTTTTTTTTTTTTCAGC } \\
\text { ACCGACCTTGTGCTTTGGGAGTGCTGGT } \\
\text { CCAAGGGCGTTAATGGACA-3' } \\
\text { Capture: } 5^{\prime} \text {-AAAAAAAAAAAAAAAA- } \\
\left(\mathrm{CH}_{2} \mathrm{O}\right)_{3}\left(\mathrm{CH}_{2}\right) 3-\mathrm{SH}-3^{\prime}\end{array}$ & $\begin{array}{l}\text { Aptamer targets the } \\
\text { receptor-binding site }\end{array}$ & $0-1000$ PFU mL ${ }^{-1}$ & $<10 \mathrm{PFU} \mathrm{mL} \mathrm{m}^{-1}$ & SERS & [89] \\
\hline 12 & SARS-CoV-2 & RNA & $\begin{array}{l}\text { Cy3-Streptavidin } \\
\text { (Сy3-SA) }\end{array}$ & NR & $\begin{array}{l}\text { Aptamer targets } \\
\text { receptor-binding } \\
\text { domain }\end{array}$ & NR & $37 \mathrm{nM}$ & Fluorometric & {$[90]$} \\
\hline
\end{tabular}




\subsection{Label-Free Opto-Electrochemical Aptasensors for Virus Detection}

The labelling process not only affects the aptamer's target-binding affinity, but also adds operational complexity and cost. As a result, for sensing applications, a label-free method is more preferred as it helps in the detection of target molecules in their natural form, because they are not altered through labelling procedure [92-94]. The BRE is not labelled with redox chemicals in label-free techniques. Instead, the aptamers are functionalized on the electrode surface, and electrochemical methods (for instance CV and EIS) are used to identify the target-aptamer interaction. Electroactive compounds for instance ferricyanide and ruthenium complexes $\left.\left(\left[\mathrm{Fe}(\mathrm{CN})_{6}\right]^{3-/ 4-} \text { and } \mathrm{Ru}(\mathrm{NH} 3)_{6}\right]^{3+}\right)$ that may attach electrostatically or interact diffusively (attraction/repulsion) with the aptamers are used in these electrochemical approaches. As these systems are more reliable and effective, researchers are exploring label-free aptasensors worldwide for the detection of different categories of biochemical molecules, bacteria, viruses, and mammalian cells. In this section, we focus on recent studies, especially in last 3 years, for the detection of various classes of viruses that are creating a major impact on human health and the economy. One such example is the aptamer-dependent detection of dengue virus belonging to the Flavi virus family causing dengue fever. This is one of the endemic diseases in tropical and subtropical regions, affecting around $40 \%$ of the world population [95]. The existing diagnostic methods of dengue fever are considered as expensive, time-consuming, and too complex to be used in remote areas, especially in places where infrastructure is not well established. Although many POC devices have been developed so far, they show some limitations relating to time consumption, and even specificity and selectivity $[96,97]$. To overcome this situation, for the first time in the year 2020, Rashid et al. have fabricated an electrochemical aptasensor for the detection of Dengue fever by targeting its NS1 protein [98]. NS1 is a non-structural protein which is considered as a specific biomarker for dengue fever $[99,100]$. The device was fabricated by targeting the specific interaction between the NS1-aptamer and the polymer-induced AuNPs. Cationic polymers, i.e., polyethyleneimine, aptamer and NS1, were deposited on the AuNPs, and this aggregation formed a duplex structure. The structural transition between the aptamer/polymer duplex and the aptamer/target complex produced the electrochemical signal. The developed aptasensor showed the improved dynamic range between $3-160 \mathrm{ng} \mathrm{mL}^{-1}$ with a LOD value of $\sim 0.3 \mathrm{ng} \mathrm{mL}^{-1}$. The cost-effectiveness and inherent flexibility of this method could be utilized to pave a way towards the effective diagnosis of Dengue virus and other infectious diseases. Recently, in the year 2021, Junior et al. have designed a more sensitive electrochemical aptasensor for targeting the same. DNA aptamers and 6-mercapto-1-hexanol were immobilised on the surface of gold electrodes to form a self-assembled monolayer. The ratio of aptamer and 6-mercapto-1-hexanol on the surface was optimised to obtain the enhanced signal and the modified electrode surface was characterised by EIS and atomic force microscopy. The non-specific interaction on the surface was blocked by using bovine serum albumin that helps in stabilising the NS1 solution. The sensor showed different LODs of 0.05, 0.022 and $0.025 \mathrm{ng} / \mathrm{mL}$, based on the serotype samples [101].

Infectious diseases are becoming the major driver of high morbidity and mortality rates worldwide. One of the major contributors to this scenario are viral infections. Human immunodeficiency virus (HIV) is amongst the top 5 contributors to infectious diseases globally [102-104]. Thus, there is an urgent requirement to find capable and impactful strategies that help towards the better treatment of such infectious diseases. The first step towards achieving this is the simple, cost-effective and fast detection method of such infectious diseases. In the year 2020, Caglayan et al. tried to monitor HIV Type 1 by developing an optical aptasensor. The aptasensor targeted the Tat (trans-activator of transcription) protein that consisted of 101 amino acids and played a key role in controlling the first stage of the replication cycle of HIV-1. The detection was based on the interaction between HIV-Tat protein and the anti-Tat aptamer that caused changes in spectroscopic ellipsometry and in the surface plasmon resonance-enhanced total internal reflection ellipsometry (Figure 5). Ellipsometry is a well-known phenomenon for the characterisation of ultra-thin-film, in 
which the change in polarisation state shows surface deposition in terms of the ellipsometric angles, psi $(\Psi)$ and delta $(\Delta)$. The developed device shows a wider dynamic range of 1.0-500 nM with an LOD of $1 \mathrm{pM}$ [105]. In 2021, another study was conducted for the detection of HIV, targeting a different binding site, i.e., p24-HIV protein-using aptasensor technology [106]. The aptasensor was designed by using a screen-printed electrode which was modified through the dispersion of graphene quantum dots (GQD) by electrodeposition. This modification helps in promoting the reduction of the oxygenated groups present on the surface of material, decreases solubility and enhances depositions of GQD. Furthermore, the aptamer was immobilized onto the electrode, forming a covalent interaction between the carboxylic group of material and the amino group of aptamers. The p24-HIV protein was measured by the electrochemical method and the fabricated aptasensor showed a dynamic range of $0.93 \mathrm{ng} \mathrm{mL}^{-1}$ to $93 \mathrm{mg} \mathrm{mL}^{-1}$ and an LOD of $51.7 \mathrm{pg} \mathrm{mL}^{-1}$.

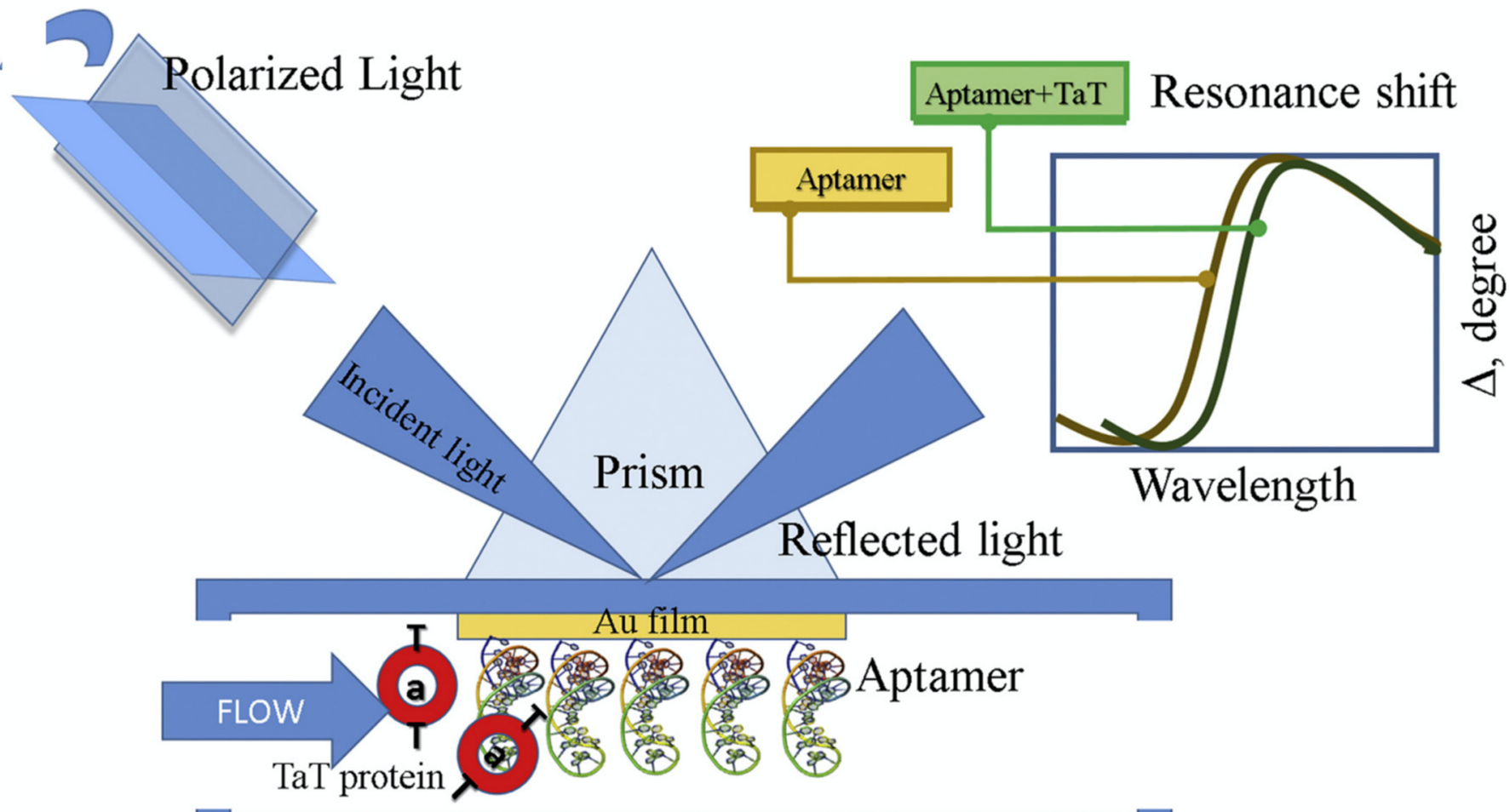

Figure 5. Pictorial representation of RNA aptasensor for the detection of HIV-Type 1 based on spectrophometric ellipsometry by targeting Tat protein (reprinted with permission from [105]. Copyright 2019 Elsevier).

Similarly, hepatitis $\mathrm{C}$ virus (HCV) infection is also a health burden worldwide, with around 170 million chronically infected people. HCV mainly infects the hepatocytes and enter the body through hepatic sinusoids causing progressive liver disease. Therefore, utilizing the aptamer-based technology in the year 2017, an electrochemical aptasensor was designed for the ultra-sensitive detection of HCV by Ghanbari et al. The aptasensor was designed by modifying glassy carbon electrodes through the immobilisation of GQDs on its surface. GQDs proved to be a more suitable substrate for aptamers, due to $\pi-\pi$ stacking interactions and the hydrophobic plane that helps in improving the aptamer absorption on the surface of electrode. The developed device directly targets the core antigen of the HCV, and the EIS method was used to confirm the monitoring process. The sensor shows two dynamic ranges, i.e., $10-70 \mathrm{pg} \mathrm{mL}^{-1}$ for a lower concentration, and $70-400 \mathrm{pg} \mathrm{mL}^{-1}$ for a higher concentration of the HCV core antigen, with a detection limit of $3.3 \mathrm{pg} \mathrm{mL}^{-1}$. The accuracy and efficiency of the aptasensor has also been checked in human serum samples, showing promising results [107]. In a recent study, Rahmati 
et al., 2021, designed an advanced and more sensitive electrochemical-based aptasensor for the detection of $\mathrm{HCV}$ [108]. In this detection system, the porous $3 \mathrm{D}-\mathrm{NiCo}_{2} \mathrm{O}_{4}$ nanowire was bombarded in an $\mathrm{N}$-doped carbon thin layer, showing morphology like a sea urchin, as confirmed by field emission scanning-electron microscopy (FE-SEM). The generated $\mathrm{N}-\mathrm{C} @ \mathrm{NiCo}_{2} \mathrm{O}_{4}$ nanowire combines the electrochemical benefits of $\mathrm{Co}$ and $\mathrm{Ni}$ species which show significantly specific active sites, greater capacitance, and better conductivity. More importantly, the layer of carbon helps in improving nanowires' stability, porosity and conductivity. The 3D N-C@ $\mathrm{NiCO}_{2} \mathrm{O}_{4}$ nanowires were used to augment the load of the HCV core antigen aptamer on the surface of the electrode, resulting in a substantial improvement in sensitivity. The developed aptasensor shows a dynamic range between $0.5 \mathrm{fg} \mathrm{mL}^{-1}$ to $0.12 \mathrm{pg} \mathrm{mL}^{-1}$ with an LOD of $0.16 \mathrm{fg} \mathrm{mL}^{-1}$.

Another virus majorly responsible for substantial economic loss globally is the Norovirus, which causes acute viral gastroenteritis. Noroviruses are infectious, and possesses high thermal stability and an ineffectiveness towards more common disinfectants and sanitizers. It becomes necessary to develop a fast, selective, sensitive and cost-effective bioanalytical sensing prototype for Norovirus detection. Recently, in 2021, Jiang et al. developed an electrochemical 3D aptasensor for the analysis of norovirus [109]. The SPCE was used, and a working electrode was developed by covering the head of the ball with the carbon ink of a pin, which made a 3D hybrid electrochemical aptasensor. This design of movable spherical working electrodes assisted in increasing specificity. The working electrode was further patterned with phosphorene-gold nanocomposites, and the nano composite was fabricated by the process of in situ reduction of phosphorene nanosheets on chloroauric acid. The developed device shows a broad dynamic range of $1 \mathrm{ng} \mathrm{mL}^{-1}-10 \mu \mathrm{g} \mathrm{mL} \mathrm{L}^{-1}$ and an LOD of $0.28 \mathrm{ng} \mathrm{mL}^{-1}$. Table 2 describes the target transduction system, aptamer sequence, dynamic range, LOD, etc. 
Table 2. Label-free opto-electrochemical aptasensor for virus detection.

\begin{tabular}{|c|c|c|c|c|c|c|c|c|}
\hline Sl.No & Target & $\begin{array}{l}\text { Target Genetic } \\
\text { Material (DNA/RNA) }\end{array}$ & Aptamer Sequence & Binding Description & Detection Range & LOD & Detection Method & References \\
\hline 1 & p24-HIV & RNA & NR & $\begin{array}{l}\text { Aptamer binds to capsid } \\
\text { protein of target }\end{array}$ & $0.93 \mathrm{ng} \mathrm{mL}^{-1}-93 \mathrm{mg} \mathrm{mL}^{-1}$ & $51.7 \mathrm{pg} \mathrm{mL}^{-1}$ & Electrochemical & [106] \\
\hline 2 & Flavivirus & RNA & 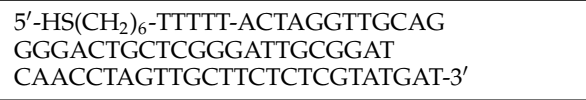 & $\begin{array}{l}\text { Aptamer binds to the } \\
\text { surface of target }\end{array}$ & $0.01-100 \mathrm{ng} \mathrm{mL}^{-1}$ & $0.022 \mathrm{ng} \mathrm{mL}^{-1}$ & Electrochemical & [101] \\
\hline 3 & $\mathrm{HCV}$ & RNA & $\begin{array}{l}\text { 5'-NH2-ACTATACACAAAAATAACACGA } \\
\text { CCGACGAAAAAACACAACC-3' }\end{array}$ & $\begin{array}{l}\text { Aptamer binds to target } \\
\text { surface }\end{array}$ & $0.5 \mathrm{fg} \mathrm{mL}^{-1}-0.12 \mathrm{pg} \mathrm{mL}^{-1}$ & $0.16 \mathrm{fg} \mathrm{mL}^{-1}$ & Impedimetric & [108] \\
\hline 4 & $\begin{array}{l}\text { Inactivated } \\
\text { H1N1 }\end{array}$ & RNA & NR & $\begin{array}{l}\text { Multivalent binding of } \\
\text { aptamer to target }\end{array}$ & NR & $0.9{\mathrm{pg} \mu \mathrm{L}^{-1}}^{-1}$ & Electrochemical & [110] \\
\hline 5 & H1N1 & RNA & $\begin{array}{l}\text { 5'-TACTGCACACGACACCGACTGTCA } \\
\text { CCATCACCTCGGCGCA-3' }\end{array}$ & $\begin{array}{l}\text { Aptamer binds to surface } \\
\text { of target }\end{array}$ & $10^{1} \mathrm{PFU} \mathrm{mL} L^{-1}-10^{4} \mathrm{PFU} \mathrm{mL} L^{-1}$ & 3.7 PFU mL ${ }^{-1}$ & Electrochemical & [111] \\
\hline 6 & Norovirus & RNA & 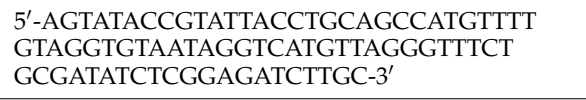 & $\begin{array}{l}\text { Aptamer targets capsid } \\
\text { protein of target }\end{array}$ & $100 \mathrm{pM}-3.5 \mathrm{nM}$ & $100 \mathrm{pM}$ & Electrochemical & [112] \\
\hline 7 & Norovirus & RNA & $\begin{array}{l}\left.\text { 5'-SH-(CH})_{2}\right)_{6} \text {-GGGAATTCGAGCTCGGTACCG } \\
\text { GCACAAGCATATGGACTCCTCTGAACCTACG } \\
\text { ATGTAGTACCTGCAGGCATGCAAGCTTGG-3' }\end{array}$ & $\begin{array}{l}\text { Aptamer binds to surface } \\
\text { of target }\end{array}$ & $0.25 \mathrm{fg} \mathrm{mL}^{-1}-1.5 \mathrm{fg} \mathrm{mL}$ fg mL $\mathrm{mL}^{-1}$ & $\begin{array}{l}0.018 \mathrm{fg} \mathrm{mL}^{-1}(\mathrm{CV}) \\
0.0016 \mathrm{fg} \mathrm{mL}^{-1}(\mathrm{SWV}) \\
\text { and } 0.001 \mathrm{fg} \mathrm{mL}^{-1} \text { (EIS) }\end{array}$ & Electrochemical & [113] \\
\hline 8 & $\begin{array}{l}\text { Murine } \\
\text { Norovirus }\end{array}$ & RNA & $\begin{array}{l}\text { 5'-GCTAGCGAATTCCGTACGAAGGGCGAAT } \\
\text { TCCACATTGGGCTGCAGCCCGGGG GATCC-3' }\end{array}$ & $\begin{array}{l}\text { Target induces aptamer to } \\
\text { desorp from the surface }\end{array}$ & $\begin{array}{l}200-10,000 \text { viruses } \mathrm{mL}^{-1} \\
1320-19,800 \text { viruses } \mathrm{mL}^{-1} \\
3300-33,000 \text { viruses } \mathrm{mL}^{-1}\end{array}$ & $\begin{array}{l}30 \text { virusesmL } \\
50 \text { virusesmL } \\
-1 \\
80 \text { viruses } \mathrm{mL}^{-1}\end{array}$ & Colorimetric & [114] \\
\hline 10 & $\mathrm{HCV}$ & RNA & $\begin{array}{l}\text { 5'-CTATACACAAAAATAACACGACCGACGAA } \\
\text { AAAACACAACC-3' }\end{array}$ & $\begin{array}{l}\text { Aptamer targets the core } \\
\text { antigen }\end{array}$ & $5 \mathrm{fg} \mathrm{mL}^{-1}-1.0 \mathrm{pg} \mathrm{mL}^{-1}$ & $1.67 \mathrm{fg} \mathrm{mL}^{-1}$ & Electrochemical & [116] \\
\hline 11 & Papillomavirus & RNA & $\begin{array}{l}\text { 5'-GGGAACAAAAGCUGCACAGGUUACCC } \\
\text { CCGCUUGGGUCUCC-3' }\end{array}$ & $\begin{array}{l}\text { Aptamer binds to surface of } \\
\text { the target }\end{array}$ & $9.6-201.6 \mathrm{ng} \mathrm{mL}^{-1}$ & $9.6 \mathrm{ng} \mathrm{mL}^{-1}$ & Colorimetric & [117] \\
\hline 12 & SARS-CoV-2 & RNA & NR & $\begin{array}{l}\text { Aptamer binds to the } \\
\text { nucleocapsid binding region }\end{array}$ & $1 \mathrm{fM}-100 \mathrm{pM}$ & $0.389 \mathrm{fM}$ & Electrochemical & {$[118]$} \\
\hline 13 & SARS-CoV-2 & RNA & $\begin{array}{l}5^{\prime}-\mathrm{NH}_{2}-\left(\mathrm{CH}_{2}\right)_{6} \text {-CAGCACCGACCTTGTGCTTTGGG } \\
\text { AGTGCTGGTCCAAGGGCGTTAATGGACA-3' }\end{array}$ & $\begin{array}{l}\text { Aptamer binds to the RBD } \\
\text { of the target }\end{array}$ & $0.5-32.0 \mathrm{nM}$ & $0.12 \mathrm{nM}$ & Electrochemical & [119] \\
\hline 14 & AIV H5N1 & RNA & NR & $\begin{array}{l}\text { Aptamer binds to the } \\
\text { surface of the target }\end{array}$ & $0.128-1.28 \mathrm{HAU}$ & $0.128 \mathrm{HAU}$ & SPR & [120] \\
\hline 15 & SARS-CoV-2 & RNA & $\begin{array}{l}5^{\prime} \text {-MeBIN/CAGCACCGACCTTGTGCTTTGGG } \\
\text { AGTGCTGGTCCAAGGGCGTTAATGGACA/ } \\
\text { 3ThioMC-3' }\end{array}$ & Aptamer targets RBD & NR & $1 \mathrm{ag} \mathrm{mL}^{-1}$ & Electrochemical & [121] \\
\hline
\end{tabular}


Table 2. Cont.

\begin{tabular}{|c|c|c|c|c|c|c|c|c|}
\hline S1.No & Target & $\begin{array}{l}\text { Target Genetic } \\
\text { Material (DNA/RNA) }\end{array}$ & Aptamer Sequence & Binding Description & Detection Range & LOD & Detection Method & References \\
\hline 16 & SARS-CoV-2 & RNA & 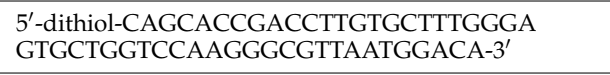 & $\begin{array}{l}\text { Target induces } \\
\text { receptor-binding domain }\end{array}$ & NR & $\begin{array}{l}0.09 \text { (for } 99 \% \text { of } \\
\text { aptamer) }\end{array}$ & SERS & [122] \\
\hline 17 & SARS-CoV-2 & RNA & $\begin{array}{l}\text { S1 Aptamer: 5'-Biotin-CAGCACCGACCTTGTGCTTT } \\
\text { GGGAGTGCTGGTCCAAGGGCGTTAATGGACA-3' } \\
\text { S1 Aptamer-T (5'-Biotin-TTTTTCAGCACCGACCTT } \\
\text { GTGCTTTGGGAGTGCTGGTCCAAGGGCGTTAAT } \\
\text { GGACA-3') } \\
\text { N Aptamer-T (5'-Biotin-TTTTTTGCAATGGTACG } \\
\text { GTACTTCCGGATGCGGAAACTGGCTAATTGGTG } \\
\text { AGGCTGGGGCGGTCGTGCAGCAAAAGTGCAC } \\
\text { GCTACTTTGCTAA-3') }\end{array}$ & Aptamer binds to the RBD & $1 \mathrm{nM}-100 \mathrm{nM}$ & $0.26 \mathrm{nM}$ & LSPR & [123] \\
\hline 18 & SARS-CoV-2 & RNA & $\begin{array}{l}\text { 5'-SH-(A15) CAGCACCGACCTTGTGCTTTGGGA } \\
\text { GTGCTGGTCCAAGGGCGTTAATGGACA-3' }\end{array}$ & $\begin{array}{l}\text { Aptamer binds to } S \text { protein } \\
\text { of target }\end{array}$ & $0.5-8 \mu \mathrm{g} \mathrm{mL}^{-1}$ & $72 \mathrm{ng} \mathrm{mL}^{-1}$ & Photoelectrochemical & {$[124]$} \\
\hline
\end{tabular}




\subsection{Aptasensors for COVID-19 Detection}

In late 2019, the outbreak of the novel severe acute respiratory syndrome coronavirus 2 (SARS-CoV-2) led to the COVID-19 pandemic that has drastically impacted the human population, leaving the world clueless, and in an unimaginable situation. PCR, which detects the viral RNA, and serological screening by detecting antibodies generated in response to the infection, are the two primary screening procedures for confirming SARS-CoV2 [125-128]. However, new methods are urgently needed due to the detection complexity, expense, and relatively longer analysis period of the present approaches. Therefore, aptasensor technology has been explored to prepare a rapid, selective, and sensitive method for the identification of SARS-CoV-2. In one of the studies, a D-shaped plastic optical fibre (POF)-based aptasensor has been designed to detect the spike protein of SARS-CoV-2. A specific aptamer sequence was immobilized on polyethylene glycol, which was further deposited on AuNPs, attached on POFs. The author utilizes the high sensitivity of surface plasmon resonance for monitoring the protein binding on the POF probe. The designing of the aptasensor for SARS-CoV-2 glycoprotein was performed by targeting its receptorbinding domain. The aptasensor had offered a considerably lower LOD of about $37 \mathrm{nM}$. The specificity of the designed aptasensor was also checked by confirming the detection within the various similar interfering molecules, such as the MERS spike protein. This type of sensing design encourages further developments, with the aim of producing a small size, portable laboratory diagnostic tool [90]. In the ongoing scenario, another aptasensor has been reported for the detection of SARS-CoV-2, targeting the receptor-binding domain in the spike protein (S-protein). The incubation time of the aptamer, target, and potential pulse time for AuNPs deposition was initially examined by using the glassy carbon electrode. The aptamer was decorated on AuNPs, and the detection of the S-protein in the complex of aptamer-target was performed using the photo-induced force microscopy mapped from 770 to $1910 \mathrm{~cm}^{-1}$. EIS was used for the final detection of the S-protein of SARS-CoV-2 after the incubation time of $40 \mathrm{~min}$. The device shows the acceptable analytical parameters, including an LOD of $1.30 \mathrm{pM}(66 \mathrm{pg} / \mathrm{mL})$ [67]. Similarly, the Tabrizi group have developed an electrochemical aptasensor for SARS-CoV-2 by targeting its receptor-binding domain [119]. Quantum dots were used in sensor fabrication by modification with graphitic carbon nitride (gC3N4) and cadmium sulphide (CdS). The CdS QDs-gC3N4 nanocomposite was dissolved in a chitosan-containing solution to form Chitosan/CdS-gC3N4 nanocomposite. The developed aptasensor shows a measurable range of 0.5-32.0 nM, and an LOD of $0.12 \mathrm{nM}$.

Ramanathan et al. developed a portable POC aptasensing device in 2021, for the impedimentary-based identification of SARS-CoV-2 by targeting its nucleocapsid protein (NCP). The system was fabricated by utilizing a $10 \mu \mathrm{m}$ gap-sized gold interdigitated electrode (AuIDE) and the electrode surface was improvised with a silane group. Furthermore, $\sim 20 \mathrm{~nm}$ of diamond was deposited on the modified electrode surface which helped in enhancing the detection of NCP (Figure 6A). The characterization of the diamond-enhanced AuIDE was performed by using XRD, XPS and FTIR analysis. EIS was implemented for the evaluation of SARS-CoV-2 NCP in a spiked human serum sample. The fabricated aptasensor shows good selectivity, linear dynamic ranges from $1 \mathrm{fM}$ to $100 \mathrm{pM}$, and a lower LOD of $0.389 \mathrm{fM}$. The aptasensor was also checked for its stability and reusability and showed $\sim 30-33 \%$ of activity loss after 11 days of analysis. Not only that, the interaction between NCP aptamer and protein was also confirmed through ELISA [118].

In addition to these, labelled aptasensing mechanisms have also been utilized for the detection of SARS-CoV-2. Tian et al. 2021 have developed a labelled aptasensor for the detection of SARS-CoV-2 by targeting its NCP. A dual aptamer based electrochemical prototype was constructed by using metal organic frameworks MIL-53 (Al) deposited on Au@Pt nanoparticles. Firstly, the two aptamers, i.e., N48 and N61, have been immobilized on the gold electrode surface to target the biomarker of nCoV, i.e., NCP. The Au@Pt/MIL-53 composites decorated with horseradish peroxidase and hemin/G-quadruplex DNAzyme were used as a signal nano probe (Figure 6B). The nanoprobe was used to enhance the signal 
of the aptasensor in the presence of hydrogen peroxide through the co-catalysed oxidation of hydroquinone. The detection system, i.e., the aptamer-protein-nanoprobe, demonstrated a broad linear range from 0.025 to $50 \mathrm{ng} \mathrm{mL}^{-1}$ with an LOD of $8.33 \mathrm{pg} \mathrm{mL}^{-1}$ [88].

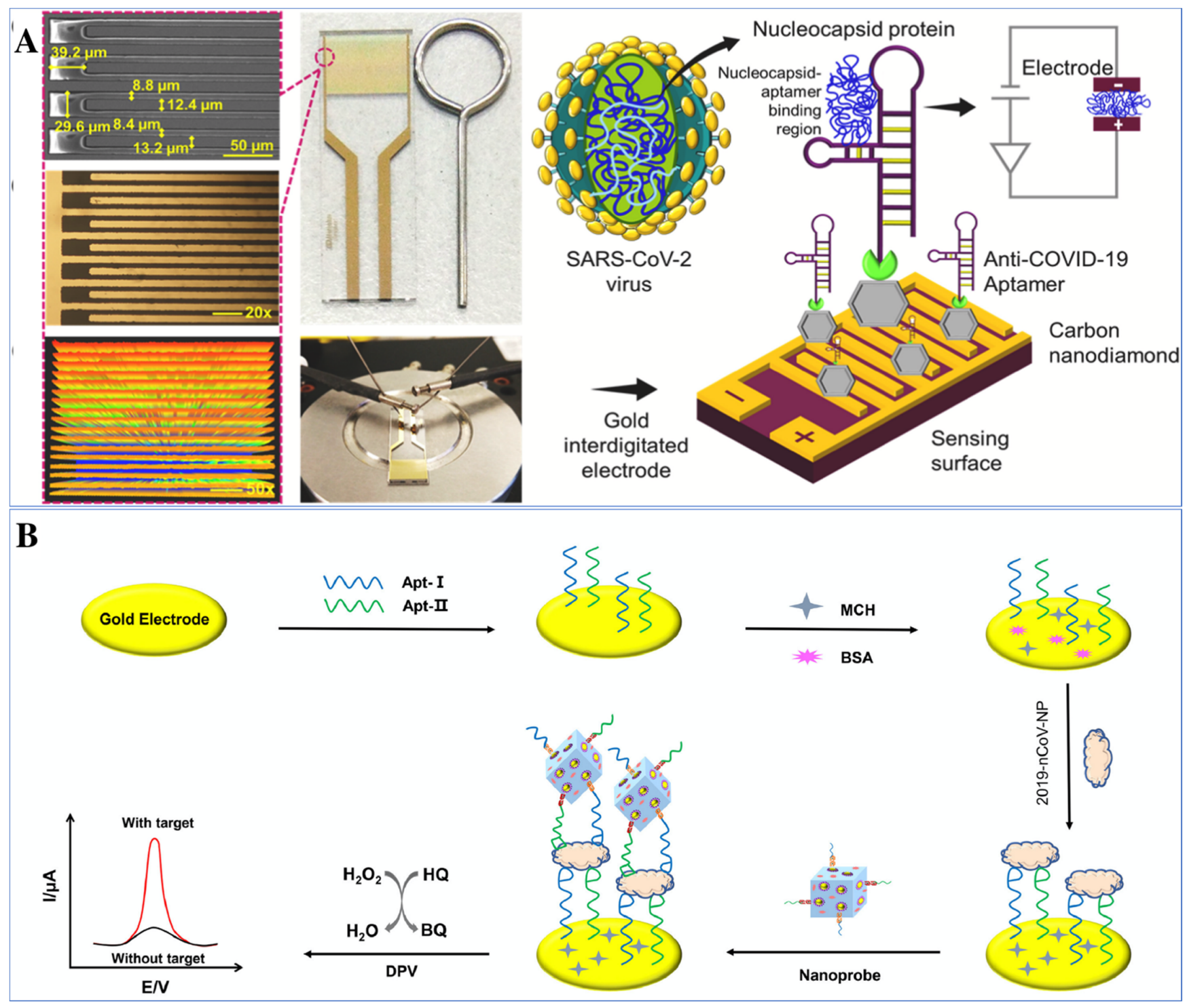

Figure 6. Illustration of electrochemical aptasensors for the detection of SARS-CoV-2. (A) Schematic of nucleocapsid protein detection of SARS-CoV-2 through immobilization of anti-NCP aptamer on diamond-enhanced gold interdigitated electrode (reprinted with permission from [118]. Copyright 2021 Elsevier) (B) Representation of dual-aptamer-based biosensor for nucleocapsid protein detection of SARS-CoV-2 by utilizing metal organic framework decorated with Au@Pt nanoparticle (reprinted with permission from [88]. Copyright 2021 Elsevier).

After a detailed study of recently published papers, with particular focus on the last 3 years, of label and label-free aptasensors focusing on optical and electrochemical readout systems, we are able to provide a comparison between these two systems. The study was mainly carried out by specifying the target, i.e., viruses, as viral infection has become one of the major infectious diseases throughout the world. Hence, in Table 3, the advantages and disadvantages of these two methods (optical and electrochemical) are tabulated to provide a clearer idea towards the aptasensors. 
Table 3. A brief overview of the advantages and limitations of optical and electrochemical aptasensors for virus detection.

\begin{tabular}{llll}
\hline Transducer Type & Advantages & Limitations & References \\
\hline Optical & $\begin{array}{l}\text { Real-time detection; } \\
\text { reliable, high sensitivity }\end{array}$ & $\begin{array}{l}\text { Sensitive to the surrounding } \\
\text { environment; surface } \\
\text { modification is one of the } \\
\text { main challenges; bulky } \\
\text { optical devices required }\end{array}$ & {$[114,129]$} \\
\hline Electrochemical & $\begin{array}{l}\text { Simplicity, miniaturization, } \\
\text { low cost real-time } \\
\text { detection; the possibility of } \\
\text { continuous analysis on } \\
\text { different analytes }\end{array}$ & $\begin{array}{l}\text { Need redox elements to } \\
\text { enhance the current } \\
\text { production; time consuming; } \\
\text { sensitive to the surrounding } \\
\text { environment }\end{array}$ & {$[83,87]$} \\
\hline
\end{tabular}

\section{Conclusions and Future Perspective}

The growth of the biosensors industry is vast and tremendous, as a large number of devices are either already commercially available, or being developed in academic laboratories. The advancement of different techniques, and the emergence of rapid prototyping methods have helped towards the tremendous growth of biosensors in the last 60 years, but still this field has a long way to go. During the sensing process, there is a major role played by the BRE, this could be enzymes, antibodies, nucleic acids, aptamers, etc. Initially, antibodies were predominantly used as BRE, but they were accompanied by various other issues, i.e., higher production cost and time, immunogenicity, etc. Thus, industries and scientists needed a more suitable, specific and cost-effective BRE, that leads to the emergence of aptamers. Aptamers prove to be an excellent BRE in every aspect, ranging from greater specificity to cheap production. Viruses are one of the most infectious, deadly disease-causing agents which impact the human population worldwide. The implication of aptamers in developed sensors for the detection of different kinds of viruses has been explained and discussed in detail in this review. Different globally developed aptasensor utilizing various nanomaterials and targeting different classes of viruses are illustrated and discussed in tabulated form, to provide a broader idea to the readers. The above explained examples highlight many promises to develop rapid, cheap, and specific aptasensing prototypes. Even after such enormous growth and development, commercial availability of these devices is still lacking. During the time of COVID-19 pandemic, laboratorial methods are used in most places, initially. Even after the development of numerous aptasensors and the commercialization of a few kits, traditional methods are still in use, especially in developing and under-developed countries. Therefore, to encounter the various issues related with aptasensors and to maximise their impact, we need to overcome several issues: first, minimising the cost of aptasensors to improve their use in developing countries; second, the selection and designing procedure to make specific aptamers need to be simplified. Finally, researchers need to focus on new technologies that can help in creating more advanced, user-friendly rapid detection devices.

Author Contributions: Conceptualization, P.C.; writing—original draft preparation, D.; writingreview and editing, D., D.S.D., R.K. (Rohini Kumari), S.M., R.K. (Rahul Kumar), P.C.; visualization, P.C.; supervision, P.C. All authors have read and agreed to the published version of the manuscript.

Funding: This research was funded by IIT (BHU) Varanasi seed grant, grant number (IIT (BHU)/ Budget/19-(14)/2020-21/18792).

Institutional Review Board Statement: Not applicable.

Informed Consent Statement: Not applicable.

Data Availability Statement: Not applicable. 
Acknowledgments: Pranjal Chandra acknowledge Pramod Kumar Jain, Director of the Indian Institute of Technology (BHU) Varanasi, India for encouragement and providing the necessary facility for completion of this work. Author Divya acknowledge her PhD research fellowship (PMRF) by MHRD. Author Supratim Mahapatra acknowledge DST INSPIRE for his research fellowship.

Conflicts of Interest: The authors declare no conflict of interest.

\section{References}

1. Özmen, E.N.; Kartal, E.; Turan, M.B.; Yazıcığlu, A.; Niazi, J.H.; Qureshi, A. Graphene and carbon nanotubes interfaced electrochemical nanobiosensors for the detection of SARS-CoV-2 (COVID-19) and other respiratory viral infections: A review. Mater. Sci. Eng. C 2021, 129, 112356. [CrossRef]

2. COVID Live-Coronavirus Statistics-Worldometer. Available online: https://www.worldometers.info/coronavirus / (accessed on 30 December 2021).

3. Hrdy, J.; Vasickova, P. Virus detection methods for different kinds of food and water samples-The importance of molecular techniques. Food Control 2022, 134, 108764. [CrossRef]

4. Kode, S.S.; Pawar, S.D.; Tare, D.S.; Mullick, J. Application of frozen and stored glutaraldehyde-fixed turkey red blood cells for hemagglutination and hemagglutination inhibition assays for the detection and identification of influenza viruses. J. Virol. Methods 2021, 289, 114046. [CrossRef]

5. Abid, S.A.; Ahmed Muneer, A.; Al-Kadmy, I.M.S.; Sattar, A.A.; Beshbishy, A.M.; Batiha, G.E.S.; Hetta, H.F. Biosensors as a future diagnostic approach for COVID-19. Life Sci. 2021, 273, 119117. [CrossRef]

6. Jiang, Z.; Feng, B.; Xu, J.; Qing, T.; Zhang, P.; Qing, Z. Graphene biosensors for bacterial and viral pathogens. Biosens. Bioelectron. 2020, 166, 112471. [CrossRef]

7. Borse, V.; Chandra, P.; Srivastava, R. BioSensing, Theranostics, and Medical Devices; Springer: Singapore, 2022. [CrossRef]

8. Chandra, P.; Tan, Y.N.; Singh, S.P. Next Generation Point-of-Care Biomedical Sensors Technologies for Cancer Diagnosis; Springer: Singapore, 2017; pp. 1-396. [CrossRef]

9. Chandra, P.; Prakash, R. Nanobiomaterial Engineering: Concepts and Their Applications in Biomedicine and Diagnostics; Springer: Berlin/Heidelberg, Germany, 2020; pp. 1-294. [CrossRef]

10. Mahato, K.; Srivastava, A.; Chandra, P. Paper based diagnostics for personalized health care: Emerging technologies and commercial aspects. Biosens. Bioelectron. 2017, 96, 246-259. [CrossRef]

11. Mahato, K.; Maurya, P.K.; Chandra, P. Fundamentals and commercial aspects of nanobiosensors in point-of-care clinical diagnostics. 3 Biotech 2018, 8, 149. [CrossRef]

12. Chey, W.D.; Baker, J.; Watts, L.; Harris, A.; Shah, E. Development of a Simple, Point-of-Care Device to Test Anorectal Function in Patients with Constipation: Randomized Clinical Trial. Clin. Gastroenterol. Hepatol. 2021. [CrossRef]

13. Leggett, C.B.; Naqvi, M.; Esakoff, T.F.; Diniz, M.A.; Wong, M.S. Incorporating personal-device-based point-of-care ultrasound into obstetric care: A validation study. Am. J. Obstet. Gynecol. 2021. [CrossRef]

14. Wang, S.; Yan, X.; Yang, Y.; Qi, X.; Zhao, Y.; Li, L.; Ma, R.; Wang, L.; Dong, Y.; Sun, J.; et al. Advances and perspectives of aptasensors for the detection of tetracyclines: A class of model compounds of food analysis. Food Chem. 2021, 364, 130361. [CrossRef]

15. Ming, T.; Luo, J.; Liu, J.; Sun, S.; Xing, Y.; Wang, H.; Xiao, G.; Deng, Y.; Cheng, Y.; Yang, Z.; et al. Paper-based microfluidic aptasensors. Biosens. Bioelectron. 2020, 170, 112649. [CrossRef]

16. Zhu, Y.; Chandra, P.; Shim, Y.B. Ultrasensitive and selective electrochemical diagnosis of breast cancer based on a hydrazine-Au nanoparticle-aptamer bioconjugate. Anal. Chem. 2013, 85, 1058-1064. [CrossRef]

17. Zhu, Y.; Chandra, P.; Song, K.-M.; Ban, C.; Shim, Y.-B. Label-free detection of kanamycin based on the aptamer-functionalized conducting polymer/gold nanocomposite. Biosens. Bioelectron. 2012, 36, 29-34. [CrossRef]

18. Kumar, A.; Purohit, B.; Maurya, P.K.; Pandey, L.M.; Chandra, P. Engineered Nanomaterial Assisted Signal-amplification Strategies for Enhancing Analytical Performance of Electrochemical Biosensors. Electroanalysis 2019, 31, 1615-1629. [CrossRef]

19. Kaur, B.; Kumar, S.; Kaushik, B.K. Recent advancements in optical biosensors for cancer detection. Biosens. Bioelectron. 2022, 197, 113805. [CrossRef]

20. Noh, H.-B.; Chandra, P.; Moon, J.O.; Shim, Y.-B. In vivo detection of glutathione disulfide and oxidative stress monitoring using a biosensor. Biomaterials 2012, 33, 2600-2607. [CrossRef]

21. Divya; Mahapatra, S.; Srivastava, V.R.; Chandra, P. Nanobioengineered Sensing Technologies Based on Cellulose Matrices for Detection of Small Molecules, Macromolecules, and Cells. Biosensors 2021, 11, 168. [CrossRef]

22. Tang, R.; Xie, M.Y.; Li, M.; Cao, L.; Feng, S.; Li, Z.; Xu, F. Nitrocellulose Membrane for Paper-based Biosensor. Appl. Mater. Today 2022, 26, 101305. [CrossRef]

23. Özbek, O.; Berkel, C.; Isildak, Ö.; Isildak, I. Potentiometric urea biosensors. Clin. Chim. Acta 2022, 524, 154-163. [CrossRef]

24. Vernekar, P.R.; Purohit, B.; Shetti, N.P.; Chandra, P. Glucose modified carbon paste sensor in the presence of cationic surfactant for mefenamic acid detection in urine and pharmaceutical samples. Microchem. J. 2021, 160, 105599. [CrossRef]

25. Qi, S.; Duan, N.; Khan, I.M.; Dong, X.; Zhang, Y.; Wu, S.; Wang, Z. Strategies to manipulate the performance of aptamers in SELEX, post-SELEX and microenvironment. Biotechnol. Adv. 2022, 55, 107902. [CrossRef] 
26. Ma, K.; Li, X.; Xu, B.; Tian, W. Label-free bioassay with graphene oxide-based fluorescent aptasensors: A review. Anal. Chim. Acta 2021, 1188, 338859. [CrossRef]

27. Khan, S.; Hussain, A.; Fahimi, H.; Aliakbari, F.; Haj Bloukh, S.; Edis, Z.; Mahdi Nejadi Babadaei, M.; Izadi, Z.; Shiri Varnamkhasti, B.; Jahanshahi, F.; et al. A review on the therapeutic applications of aptamers and aptamer-conjugated nanoparticles in cancer, inflammatory and viral diseases. Arab. J. Chem. 2021, 15, 103626. [CrossRef]

28. Li, R.; An, Y.; Jin, T.; Zhang, F.; He, P. Detection of MUC1 protein on tumor cells and their derived exosomes for breast cancer surveillance with an electrochemiluminescence aptasensor. J. Electroanal. Chem. 2021, 882, 115011. [CrossRef]

29. Qi, X.; Zhao, Y.; Su, H.; Wang, L.; Li, L.; Ma, R.; Yan, X.; Sun, J.; Wang, S.; Mao, X. A label-free colorimetric aptasensor based on split aptamers-chitosan oligosaccharide-AuNPs nanocomposites for sensitive and selective detection of kanamycin. Talanta 2022 238, 123032. [CrossRef]

30. Yan, X.; Wang, Y.; Kou, Q.; Sun, Q.; Tang, J.; Yang, L.; Chen, X.; Xu, W.; Le, T. A novel aptasensor based on $\mathrm{Fe}_{3} \mathrm{O}_{4} / \mathrm{Au} / \mathrm{g}-\mathrm{C}_{3} \mathrm{~N}_{4}$ for sensitive detection of sulfameter in food matrices. Sens. Actuators B Chem. 2022, 353, 131148. [CrossRef]

31. Park, J.; Kim, M.; Kim, W.; Jo, S.; Kim, W.; Kim, C.; Park, H.; Lee, W.; Park, J. Ultrasensitive Detection of 25-hydroxy Vitamin D3 in Real Saliva Using Sandwich-type Electrochemical Aptasensor. Sens. Actuators B Chem. 2021, 355, 131239. [CrossRef]

32. Chen, X.; Chen, K.; Du, Z.; Chu, H.; Zhu, L.; He, X.; Xu, W. Fusion of binary split allosteric aptasensor for the ultra-sensitive and super-rapid detection of malachite green. J. Hazard. Mater. 2022, 425, 127976. [CrossRef]

33. Lyu, C.; Khan, I.M.; Wang, Z. Capture-SELEX for aptamer selection: A short review. Talanta 2021, 229, 122274. [CrossRef]

34. Kaur, H. Recent developments in cell-SELEX technology for aptamer selection. Biochim. Biophys. Acta-Gen. Subj. 2018, 1862, 2323-2329. [CrossRef]

35. Tuerk, C.; Gold, L. Systematic evolution of ligands by exponential enrichment: RNA ligands to bacteriophage T4 DNA polymerase. Science 1990, 249, 505-510. [CrossRef] [PubMed]

36. Ellington, A.D.; Szostak, J.W. In vitro selection of RNA molecules that bind specific ligands. Nature 1990, 346, 818-822. [CrossRef] [PubMed]

37. Qian, S.; Chang, D.; He, S.; Li, Y. Aptamers from random sequence space: Accomplishments, gaps and future considerations. Anal. Chim. Acta 2022, 339511. [CrossRef]

38. Azzouz, A.; Hejji, L.; Sonne, C.; Kim, K.H.; Kumar, V. Nanomaterial-based aptasensors as an efficient substitute for cardiovascular disease diagnosis: Future of smart biosensors. Biosens. Bioelectron. 2021, 193, 113617. [CrossRef] [PubMed]

39. Yazdian-Robati, R.; Hedayati, N.; Dehghani, S.; Ramezani, M.; Alibolandi, M.; Saeedi, M.; Abnous, K.; Taghdisi, S.M. Application of the catalytic activity of gold nanoparticles for development of optical aptasensors. Anal. Biochem. 2021, 629, 114307. [CrossRef] [PubMed]

40. Zhang, N.; Li, J.; Liu, B.; Zhang, D.; Zhang, C.; Guo, Y.; Chu, X.; Wang, W.; Wang, H.; Yan, X.; et al. Signal enhancing strategies in aptasensors for the detection of small molecular contaminants by nanomaterials and nucleic acid amplification. Talanta 2022, 236, 122866. [CrossRef]

41. Citartan, M.; Tang, T.H. Recent developments of aptasensors expedient for point-of-care (POC) diagnostics. Talanta 2019, 199, 556-566. [CrossRef] [PubMed]

42. Forouzanfar, S.; Alam, F.; Pala, N.; Wang, C. Review-A Review of Electrochemical Aptasensors for Label-Free Cancer Diagnosis. J. Electrochem. Soc. 2020, 167, 067511. [CrossRef]

43. Purohit, B.; Vernekar, P.R.; Shetti, N.P.; Chandra, P. Biosensor nanoengineering: Design, operation, and implementation for biomolecular analysis. Sens. Int. 2020, 1, 100040. [CrossRef]

44. Mahato, K.; Purohit, B.; Kumar, A.; Chandra, P. Clinically comparable impedimetric immunosensor for serum alkaline phosphatase detection based on electrochemically engineered Au-nano-Dendroids and graphene oxide nanocomposite. Biosens. Bioelectron. 2020, 148, 111815. [CrossRef]

45. Azad, U.P.; Mahapatra, S.; Divya; Srivastava, A.; Shetti, N.P.; Chandra, P. Electrochemical biosensors for monitoring of bioorganic and inorganic chemical pollutants in biological and environmental matrices. In Microbial Biodegradation and Bioremediation; Elsevier: Amsterdam, The Netherlands, 2022; pp. 509-531. [CrossRef]

46. Peeling, R.W.; Holmes, K.K.; Mabey, D. Rapid tests for sexually transmitted infections (STIs): The way forward. Sex. Transm. Infect. 2006, 82 (Suppl. S5), v1-v6. [CrossRef] [PubMed]

47. Mahato, K.; Prasad, A.; Maurya, P.K.; Chandra, P. Nanobiosensors: Next Generation Point-of-Care Biomedical Devices for Personalized Diagnosis. J. Anal. Bioanal. Tech. 2016, 7, e125. [CrossRef]

48. Mahato, K.; Kumar, S.; Srivastava, A.; Maurya, P.K.; Singh, R.; Chandra, P. Electrochemical immunosensors: Fundamentals and applications in clinical diagnostics. In Handbook of Immunoassay Technologies: Approaches, Performances, and Applications; Elsevier: Amsterdam, The Netherlands, 2018; pp. 359-414. ISBN 9780128117620.

49. Low, S.S.; Chen, Z.; Li, Y.; Lu, Y.; Liu, Q. Design Principle in Biosensing: Critical Analysis based on Graphitic Carbon Nitride (G-C3N4) Photoelectrochemical Biosensor. TrAC Trends Anal. Chem. 2021, 145, 116454. [CrossRef]

50. Mandal, R.; Baranwal, A.; Srivastava, A.; Chandra, P. Evolving trends in bio/chemical sensor fabrication incorporating bimetallic nanoparticles. Biosens. Bioelectron. 2018, 117, 546-561. [CrossRef] [PubMed]

51. Yadav, S.K.; Chandra, P.; Goyal, R.N.; Shim, Y.B. A review on determination of steroids in biological samples exploiting nanobio-electroanalytical methods. Anal. Chim. Acta 2013, 762, 14-24. [CrossRef] [PubMed] 
52. Mahato, K.; Kumar, A.; Maurya, P.K.; Chandra, P. Shifting paradigm of cancer diagnoses in clinically relevant samples based on miniaturized electrochemical nanobiosensors and microfluidic devices. Biosens. Bioelectron. 2018, 100, 411-428. [CrossRef]

53. Kumar, A.; Purohit, B.; Mahato, K.; Roy, S.; Srivastava, A.; Chandra, P. Design and Development of Ultrafast Sinapic Acid Sensor Based on Electrochemically Nanotuned Gold Nanoparticles and Solvothermally Reduced Graphene Oxide. Electroanalysis 2020, 32, 59-69. [CrossRef]

54. Mahato, K.; Purohit, B.; Bhardwaj, K.; Jaiswal, A.; Chandra, P. Novel electrochemical biosensor for serotonin detection based on gold nanorattles decorated reduced graphene oxide in biological fluids and in vitro model. Biosens. Bioelectron. 2019, 142, 111502 [CrossRef]

55. Sammi, A.; Divya; Mahapatra, S.; Kumar, R.; Chandra, P. Nano-Bio-engineered Silk Matrix based Devices for Molecular Bioanalysis. Biotechnol. Bioeng. 2021. [CrossRef]

56. Mahato, K.; Kumar, A.; Purohit, B.; Mahapatra, S.; Srivastava, A.; Chandra, P. Nanomaterial Functionalization Strategies in Bio-Interface Development for Modern Diagnostic Devices. In Biointerface Engineering: Prospects in Medical Diagnostics and Drug Delivery; Springer: Singapore, 2020; pp. 195-214.

57. Shanbhag, M.M.; Shetti, N.P.; Kulkarni, R.M.; Chandra, P. Nanostructured Ba/ZnO modified electrode as a sensor material for detection of organosulfur thiosalicylic acid. Microchem. J. 2020, 159, 105409. [CrossRef]

58. Chandra, P.; Singh, J.; Singh, A.; Srivastava, A.; Goyal, R.N.; Shim, Y.B. Gold Nanoparticles and Nanocomposites in Clinical Diagnostics Using Electrochemical Methods. J. Nanoparticles 2013, 2013, 535901. [CrossRef]

59. Chandra, P. Miniaturized label-free smartphone assisted electrochemical sensing approach for personalized COVID-19 diagnosis. Sens. Int. 2020, 1, 100019. [CrossRef] [PubMed]

60. Baranwal, A.; Chandra, P. Clinical implications and electrochemical biosensing of monoamine neurotransmitters in body fluids, in vitro, in vivo, and ex vivo models. Biosens. Bioelectron. 2018, 121, 137-152. [CrossRef] [PubMed]

61. Verma, S.; Choudhary, J.; Singh, K.P.; Chandra, P.; Singh, S.P. Uricase grafted nanoconducting matrix based electrochemical biosensor for ultrafast uric acid detection in human serum samples. Int. J. Biol. Macromol. 2019, 130, 333-341. [CrossRef]

62. Schmidt-Speicher, L.M.; Länge, K. Microfluidic integration for electrochemical biosensor applications. Curr. Opin. Electrochem. 2021, 29, 100755. [CrossRef]

63. Jain, U.; Saxena, K.; Hooda, V.; Balayan, S.; Singh, A.P.; Tikadar, M.; Chauhan, N. Emerging vistas on pesticides detection based on electrochemical biosensors-An update. Food Chem. 2022, 371, 131126. [CrossRef] [PubMed]

64. Bajpai, V.K.; Kamle, M.; Shukla, S.; Mahato, D.K.; Chandra, P.; Hwang, S.K.; Kumar, P.; Huh, Y.S.; Han, Y.-K. Prospects of using nanotechnology for food preservation, safety, and security. J. Food Drug Anal. 2018, 26, 1201-1214. [CrossRef]

65. Yu, H.; Guo, W.; Lu, X.; Xu, H.; Yang, Q.; Tan, J.; Zhang, W. Reduced graphene oxide nanocomposite based electrochemical biosensors for monitoring foodborne pathogenic bacteria: A review. Food Control 2021, 127, 108117. [CrossRef]

66. Agrahari, S.; Kumar Gautam, R.; Kumar Singh, A.; Tiwari, I. Nanoscale materials-based hybrid frameworks modified electrochemical biosensors for early cancer diagnostics: An overview of current trends and challenges. Microchem. J. 2022, 172, 106980. [CrossRef]

67. Abrego-Martinez, J.C.; Jafari, M.; Chergui, S.; Pavel, C.; Che, D.; Siaj, M. Aptamer-based electrochemical biosensor for rapid detection of SARS-CoV-2: Nanoscale electrode-aptamer-SARS-CoV-2 imaging by photo-induced force microscopy. Biosens. Bioelectron. 2022, 195, 113595. [CrossRef]

68. Ong, J.J.; Pollard, T.D.; Goyanes, A.; Gaisford, S.; Elbadawi, M.; Basit, A.W. Optical biosensors-Illuminating the path to personalized drug dosing. Biosens. Bioelectron. 2021, 188, 113331. [CrossRef] [PubMed]

69. Xavier, J.; Vincent, S.; Meder, F.; Vollmer, F. Advances in optoplasmonic sensors-Combining optical nano/microcavities and photonic crystals with plasmonic nanostructures and nanoparticles. Nanophotonics 2018, 7, 1-38. [CrossRef]

70. Chen, Y.; Liu, J.; Yang, Z.; Wilkinson, J.S.; Zhou, X. Optical biosensors based on refractometric sensing schemes: A review. Biosens. Bioelectron. 2019, 144, 111693. [CrossRef] [PubMed]

71. Chen, H.; Park, S.G.; Choi, N.; Moon, J.-I.; Dang, H.; Das, A.; Lee, S.; Kim, D.G.; Chen, L.; Choo, J. SERS imaging-based aptasensor for ultrasensitive and reproducible detection of influenza virus A. Biosens. Bioelectron. 2020, 167, 112496. [CrossRef]

72. Abstract Eun, A.J.-C.; Huang, L.; Chew, F.-T.; Li, S.F.-Y.; Wong, S.-M. Detection of Two Orchid Viruses Using Quartz Crystal Microbalance-Based DNA Biosensors. Phytopathology 2002, 92, 654-658.

73. Mokhtarzadeh, A.; Eivazzadeh-Keihan, R.; Pashazadeh, P.; Hejazi, M.; Gharaatifar, N.; Hasanzadeh, M.; Baradaran, B.; de la Guardia, M. Nanomaterial-based biosensors for detection of pathogenic virus. TrAC Trends Anal. Chem. 2017, 97, 445-457. [CrossRef]

74. Kumar, S.; Ahlawat, W.; Kumar, R.; Dilbaghi, N. Graphene, carbon nanotubes, zinc oxide and gold as elite nanomaterials for fabrication of biosensors for healthcare. Biosens. Bioelectron. 2015, 70, 498-503. [CrossRef]

75. Wang, Q.; Qin, X.; Geng, L.; Wang, Y. Label-Free Electrochemical Aptasensor for Sensitive Detection of Malachite Green Based on $\mathrm{Au}$ Nanoparticle/Graphene Quantum Dots/Tungsten Disulfide Nanocomposites. Nanomaterials 2019, 9, 229. [CrossRef]

76. Rozenblum, G.T.; Pollitzer, I.G.; Radrizzani, M. Challenges in Electrochemical Aptasensors and Current Sensing Architectures Using Flat Gold Surfaces. Chemosensors 2019, 7, 57. [CrossRef]

77. Daems, E.; Moro, G.; Campos, R.; De Wael, K. Mapping the gaps in chemical analysis for the characterisation of aptamer-target interactions. TrAC Trends Anal. Chem. 2021, 142, 116311. [CrossRef] 
78. Karash, S.; Wang, R.; Kelso, L.; Lu, H.; Huang, T.J.; Li, Y. Rapid detection of avian influenza virus H5N1 in chicken tracheal samples using an impedance aptasensor with gold nanoparticles for signal amplification. J. Virol. Methods 2016, 236, 147-156. [CrossRef]

79. Xu, L.; Wang, R.; Kelso, L.C.; Ying, Y.; Li, Y. A target-responsive and size-dependent hydrogel aptasensor embedded with QD fluorescent reporters for rapid detection of avian influenza virus H5N1. Sens. Actuators B Chem. 2016, 234, 98-108. [CrossRef]

80. Mok, J.; Jeon, J.; Jo, J.; Kim, E.; Ban, C. Novel one-shot fluorescent aptasensor for dengue fever diagnosis using NS1-induced structural change of G-quadruplex aptamer. Sens. Actuators B Chem. 2021, 343, 130077. [CrossRef]

81. Kukushkin, V.I.; Ivanov, N.M.; Novoseltseva, A.A.; Gambaryan, A.S.; Yaminsky, I.V.; Kopylov, A.M.; Zavyalova, E.G. Highly sensitive detection of influenza virus with SERS aptasensor. PLoS ONE 2019, 14, 1-14. [CrossRef] [PubMed]

82. Gribanyov, D.; Zhdanov, G.; Olenin, A.; Lisichkin, G.; Gambaryan, A.; Kukushkin, V.; Zavyalova, E. Sers-based colloidal aptasensors for quantitative determination of influenza virus. Int. J. Mol. Sci. 2021, 22, 1842. [CrossRef] [PubMed]

83. Babamiri, B.; Salimi, A.; Hallaj, R. A molecularly imprinted electrochemiluminescence sensor for ultrasensitive HIV-1 gene detection using EuS nanocrystals as luminophore. Biosens. Bioelectron. 2018, 117, 332-339. [CrossRef]

84. Mohsin, D.H.; Mashkour, M.S.; Fatemi, F. Design of aptamer-based sensing platform using gold nanoparticles functionalized reduced graphene oxide for ultrasensitive detection of Hepatitis B virus. Chem. Pap. 2021, 75, 279-295. [CrossRef]

85. Xi, Z.; Gong, Q.; Wang, C.; Zheng, B. Highly sensitive chemiluminescent aptasensor for detecting HBV infection based on rapid magnetic separation and double-functionalized gold nanoparticles. Sci. Rep. 2018, 8, 9444. [CrossRef] [PubMed]

86. Weng, X.; Neethirajan, S. Aptamer-based fluorometric determination of norovirus using a paper-based microfluidic device. Microchim. Acta 2017, 184, 4545-4552. [CrossRef]

87. Kim, G.; Kim, J.; Kim, S.M.; Kato, T.; Yoon, J.; Noh, S.; Park, E.Y.; Park, C.; Lee, T.; Choi, J.W. Fabrication of MERS-nanovesicle biosensor composed of multi-functional DNA aptamer/graphene-MoS2 nanocomposite based on electrochemical and surfaceenhanced Raman spectroscopy. Sens. Actuators B Chem. 2022, 352, 131060. [CrossRef]

88. Tian, J.; Liang, Z.; Hu, O.; He, Q.; Sun, D.; Chen, Z. An electrochemical dual-aptamer biosensor based on metal-organic frameworks MIL-53 decorated with Au@Pt nanoparticles and enzymes for detection of COVID-19 nucleocapsid protein. Electrochim. Acta 2021, 387, 138553. [CrossRef]

89. Chen, H.; Park, S.G.; Choi, N.; Kwon, H.J.; Kang, T.; Lee, M.K.; Choo, J. Sensitive Detection of SARS-CoV-2 Using a SERS-Based Aptasensor. ACS Sens. 2021, 6, 2378-2385. [CrossRef]

90. Cennamo, N.; Pasquardini, L.; Arcadio, F.; Lunelli, L.; Vanzetti, L.; Carafa, V.; Altucci, L.; Zeni, L. SARS-CoV-2 spike protein detection through a plasmonic D-shaped plastic optical fiber aptasensor. Talanta 2021, 233, 122532. [CrossRef] [PubMed]

91. Song, Y.; Song, J.; Wei, X.; Huang, M.; Sun, M.; Zhu, L.; Lin, B.; Shen, H.; Zhu, Z.; Yang, C. Discovery of Aptamers Targeting the Receptor-Binding Domain of the SARS-CoV-2 Spike Glycoprotein. Anal. Chem. 2020, 92, 9895-9900. [CrossRef] [PubMed]

92. Solhi, E.; Hasanzadeh, M. Critical role of biosensing on the efficient monitoring of cancer proteins/biomarkers using label-free aptamer based bioassay. Biomed. Pharmacother. 2020, 132, 110849. [CrossRef]

93. Sook Bang, G.; Cho, S.; Lee, N.; Lee, B.R.; Kim, J.H.; Kim, B.G. Rational design of modular allosteric aptamer sensor for label-free protein detection. Biosens. Bioelectron. 2013, 39, 44-50. [CrossRef] [PubMed]

94. Nan, M.N.; Bi, Y.; Xue, H.L.; Long, H.T.; Xue, S.L.; Pu, L.M.; Prusky, D. Modification performance and electrochemical characteristics of different groups of modified aptamers applied for label-free electrochemical impedimetric sensors. Food Chem. 2021, 337, 127761. [CrossRef]

95. Alfsnes, K.; Eldholm, V.; Gaunt, M.W.; de Lamballerie, X.; Gould, E.A.; Pettersson, J.H.-O. Tracing and tracking the emergence, epidemiology and dispersal of dengue virus to Africa during the 20th century. One Health 2021, 13, 100337. [CrossRef]

96. Hosseini, S.; Azari, P.; Cardenas-Benitez, B.; Martínez-Guerra, E.; Aguirre-Tostado, F.S.; Vázquez-Villegas, P.; Pingguan-Murphy, B.; Madou, M.J.; Martinez-Chapa, S.O. A LEGO inspired fiber probe analytical platform for early diagnosis of Dengue fever. Mater. Sci. Eng. C 2020, 109, 110629. [CrossRef]

97. Tandel, K.; Kumar, M.; Bhalla, G.S.; Shergill, S.P.S.; Swarnim, V.; Sahai, K.; Gupta, R.M. Detection of dengue virus serotypes by single-tube multiplex RT-PCR and multiplex real-time PCR assay. Med. J. Armed Forces India 2021. [CrossRef]

98. Rashid, S.; Nawaz, M.H.; Marty, J.L.; Hayat, A. Label free ultrasensitive detection of NS1 based on electrochemical aptasensor using polyethyleneimine aggregated AuNPs. Microchem. J. 2020, 158, 105285. [CrossRef]

99. Kim, J.H.; Cho, C.H.; Ryu, M.Y.; Kim, J.G.; Lee, S.J.; Park, T.J.; Park, J.P. Development of peptide biosensor for the detection of dengue fever biomarker, nonstructural 1. PLoS ONE 2019, 14, e0222144. [CrossRef] [PubMed]

100. Antunes, P.; Watterson, D.; Parmvi, M.; Burger, R.; Boisen, A.; Young, P.; Cooper, M.A.; Hansen, M.F.; Ranzoni, A.; Donolato, M. Quantification of NS1 dengue biomarker in serum via optomagnetic nanocluster detection. Sci. Rep. 2015, 5, 16145. [CrossRef] [PubMed]

101. Bachour Junior, B.; Batistuti, M.R.; Pereira, A.S.; de Sousa Russo, E.M.; Mulato, M. Electrochemical aptasensor for NS1 detection: Towards a fast dengue biosensor. Talanta 2021, 233, 122527. [CrossRef]

102. Kirtane, A.R.; Verma, M.; Karandikar, P.; Furin, J.; Langer, R.; Traverso, G. Nanotechnology approaches for global infectious diseases. Nat. Nanotechnol. 2021, 16, 369-384. [CrossRef]

103. Bloom, D.E.; Cadarette, D. Infectious Disease Threats in the Twenty-First Century: Strengthening the Global Response. Front. Immunol. 2019, 10, 549. [CrossRef] 
104. Smith, K.M.; Machalaba, C.C.; Seifman, R.; Feferholtz, Y.; Karesh, W.B. Infectious disease and economics: The case for considering multi-sectoral impacts. One Health 2019, 7, 100080. [CrossRef]

105. Caglayan, M.O.; Üstündağ, Z. Spectrophotometric ellipsometry based Tat-protein RNA-aptasensor for HIV-1 diagnosis. Spectrochim. Acta-Part A Mol. Biomol. Spectrosc. 2020, 227, 117748. [CrossRef]

106. Gogola, J.L.; Martins, G.; Gevaerd, A.; Blanes, L.; Cardoso, J.; Marchini, F.K.; Banks, C.E.; Bergamini, M.F.; Marcolino-Junior, L.H. Label-free aptasensor for p24-HIV protein detection based on graphene quantum dots as an electrochemical signal amplifier. Anal. Chim. Acta 2021, 1166, 1-7. [CrossRef]

107. Ghanbari, K.; Roushani, M.; Azadbakht, A. Ultra-sensitive aptasensor based on a GQD nanocomposite for detection of hepatitis C virus core antigen. Anal. Biochem. 2017, 534, 64-69. [CrossRef]

108. Rahmati, Z.; Roushani, M.; Hosseini, H. Three-dimensional $\mathrm{NiCo}_{2} \mathrm{O}_{4}$ nanowires encapsulated in nitrogen-doped carbon networks as a high-performance aptamer stabilizer for impedimetric ultrasensitive detection of hepatitis $\mathrm{C}$ virus core antigen. Surf. Interfaces 2021, 22, 100813. [CrossRef]

109. Jiang, H.; Sun, Z.; Zhang, C.; Weng, X. 3D-architectured aptasensor for ultrasensitive electrochemical detection of norovirus based on phosphorene-gold nanocomposites. Sens. Actuators B Chem. 2022, 354, 131232. [CrossRef]

110. Bai, C.; Lu, Z.; Jiang, H.; Yang, Z.; Liu, X.; Ding, H.; Li, H.; Dong, J.; Huang, A.; Fang, T.; et al. Aptamer selection and application in multivalent binding-based electrical impedance detection of inactivated H1N1 virus. Biosens. Bioelectron. 2018, 110, 162-167. [CrossRef] [PubMed]

111. Bhardwaj, J.; Chaudhary, N.; Kim, H.; Jang, J. Subtyping of influenza A H1N1 virus using a label-free electrochemical biosensor based on the DNA aptamer targeting the stem region of HA protein. Anal. Chim. Acta 2019, 1064, 94-103. [CrossRef] [PubMed]

112. Chand, R.; Neethirajan, S. Microfluidic platform integrated with graphene-gold nano-composite aptasensor for one-step detection of norovirus. Biosens. Bioelectron. 2017, 98, 47-53. [CrossRef] [PubMed]

113. Mohsin, D.H.; Mashkour, M.S.; Fatemi, F.; Abood, E.S. Design of ultrasensitive electrochemical aptasensor for earlier detection of hepatitis B virus. Nano Biomed. Eng. 2021, 13, 150-164. [CrossRef]

114. Weerathunge, P.; Ramanathan, R.; Torok, V.A.; Hodgson, K.; Xu, Y.; Goodacre, R.; Behera, B.K.; Bansal, V. Ultrasensitive Colorimetric Detection of Murine Norovirus Using NanoZyme Aptasensor. Anal. Chem. 2019, 91, 3270-3276. [CrossRef]

115. Steinmetz, M.; Lima, D.; Viana, A.G.; Fujiwara, S.T.; Pessôa, C.A.; Etto, R.M.; Wohnrath, K. A sensitive label-free impedimetric DNA biosensor based on silsesquioxane-functionalized gold nanoparticles for Zika Virus detection. Biosens. Bioelectron. 2019, 141, 111351. [CrossRef]

116. Ghanbari, K.; Roushani, M. A nanohybrid probe based on double recognition of an aptamer MIP grafted onto a MWCNTs-Chit nanocomposite for sensing hepatitis C virus core antigen. Sens. Actuators B Chem. 2018, 258, 1066-1071. [CrossRef]

117. Zhu, L.; Zhao, Y.; Yao, S.; Xu, M.; Yin, L.; Zhai, X.; Teng, X. A colorimetric aptasensor for the simple and rapid detection of human papillomavirus type $16 \mathrm{~L} 1$ proteins. Analyst 2021, 146, 2712-2717. [CrossRef]

118. Ramanathan, S.; Gopinath, S.C.B.; Ismail, Z.H.; Md Arshad, M.K.; Poopalan, P. Aptasensing nucleocapsid protein on nanodiamond assembled gold interdigitated electrodes for impedimetric SARS-CoV-2 infectious disease assessment. Biosens. Bioelectron. 2022, 197, 113735. [CrossRef] [PubMed]

119. Amouzadeh Tabrizi, M.; Nazari, L.; Acedo, P. A photo-electrochemical aptasensor for the determination of severe acute respiratory syndrome coronavirus 2 receptor-binding domain by using graphitic carbon nitride-cadmium sulfide quantum dots nanocomposite. Sens. Actuators B Chem. 2021, 345, 130377. [CrossRef] [PubMed]

120. Bai, H.; Wang, R.; Hargis, B.; Lu, H.; Li, Y. A SPR aptasensor for detection of avian influenza virus H5N1. Sensors 2012, 12, 12506-12518. [CrossRef] [PubMed]

121. Zakashansky, J.A.; Imamura, A.H.; Salgado, D.F.; Romero Mercieca, H.C.; Aguas, R.F.L.; Lao, A.M.; Pariser, J.; Arroyo-Currás, N.; Khine, M. Detection of the SARS-CoV-2 spike protein in saliva with Shrinky-Dink@ electrodes. Anal. Methods 2021, 13, 874-883. [CrossRef]

122. Stanborough, T.; Given, F.M.; Koch, B.; Sheen, C.R.; Stowers-Hull, A.B.; Waterland, M.R.; Crittenden, D.L. Optical Detection of CoV-SARS-2 Viral Proteins to Sub-Picomolar Concentrations. ACS Omega 2021, 6, 6404-6413. [CrossRef]

123. Lewis, T.; Giroux, E.; Jovic, M.; Martic-Milne, S. Localized surface plasmon resonance aptasensor for selective detection of SARS-CoV-2 S1 protein. Analyst 2021, 146, 7207-7217. [CrossRef]

124. Jiang, Z.W.; Zhao, T.T.; Li, C.M.; Li, Y.F.; Huang, C.Z. 2D MOF-Based Photoelectrochemical Aptasensor for SARS-CoV-2 Spike Glycoprotein Detection. ACS Appl. Mater. Interfaces 2021, 13, 49754-49761. [CrossRef]

125. Baranwal, A.; Mahapatra, S.; Purohit, B.; Roy, S.; Chandra, P. Insights into Novel Coronavirus and COVID-19 Outbreak. In Diagnostic Strategies for COVID-19 and Other Coronaviruses; Springer: Singapore, 2020; pp. 1-17. [CrossRef]

126. Mahapatra, S.; Baranwal, A.; Purohit, B.; Roy, S.; Mahto, S.K.; Chandra, P. Advanced Biosensing Methodologies for Ultrasensitive Detection of Human Coronaviruses. In Diagnostic Strategies for COVID-19 and Other Coronaviruses; Springer: Singapore, 2020; pp. 19-36. [CrossRef]

127. Ji, T.; Liu, Z.; Wang, G.Q.; Guo, X.; Akbar khan, S.; Lai, C.; Chen, H.; Huang, S.; Xia, S.; Chen, B.; et al. Detection of COVID-19: A review of the current literature and future perspectives. Biosens. Bioelectron. 2020, 166, 112455. [CrossRef] 
128. Ge, C.; Feng, J.; Zhang, J.; Hu, K.; Wang, D.; Zha, L.; Hu, X.; Li, R. Aptamer/antibody sandwich method for digital detection of SARS-CoV2 nucleocapsid protein. Talanta 2022, 236, 122847. [CrossRef]

129. Feng, C.; Dai, S.; Wang, L. Optical aptasensors for quantitative detection of small biomolecules: A review. Biosens. Bioelectron. 2014, 59, 64-74. [CrossRef] 